\title{
REVIEW
}

\section{Bacterial flagellin—a potent immunomodulatory agent}

\author{
Irshad A Hajam ${ }^{1}$, Pervaiz A Dar ${ }^{2}$, Imam Shahnawaz ${ }^{2}$, Juan Carlos Jaume ${ }^{2}$ and John Hwa Lee ${ }^{1}$ \\ Flagellin is a subunit protein of the flagellum, a whip-like appendage that enables bacterial motility. Traditionally, flagellin was \\ viewed as a virulence factor that contributes to the adhesion and invasion of host cells, but now it has emerged as a potent \\ immune activator, shaping both the innate and adaptive arms of immunity during microbial infections. In this review, we \\ summarize our understanding of bacterial flagellin and host immune system interactions and the role flagellin as an adjuvant, \\ anti-tumor and radioprotective agent, and we address important areas of future research interests.
}

Experimental \& Molecular Medicine (2017) 49, e373; doi:10.1038/emm.2017.172; published online 1 September 2017

\section{INTRODUCTION}

The immune system has evolved to fight off microbial invasion through the coordinated action of the innate and adaptive arms of the immunity. Innate immune cells respond to a variety of stimuli, including bacterial, viral, parasitic or fungal infections, via members of structurally related receptors termed toll-like receptors (TLRs). TLRs are evolutionarily conserved type I transmembrane receptors that provide a critical link between innate and adaptive immunity. TLRs do not possess fine specificity, such as that of BCRs, TCRs or adaptive immune receptors, but they can individually respond to a limited but specific number of microbial pathogen-associated molecular patterns (PAMPs). The interaction of PAMPs with the TLRs on innate immune cells regulates the induction of more efficient adaptive immune responses. ${ }^{1}$ TLRs mostly function as homologous or heterologous dimers, acquiring the shape of a horseshoe, which helps in the direct recognition of PAMPs. ${ }^{2,3}$ TLRs sense bacterial cell wall components, such as lipopolysaccharide (LPS) (TLR-2/4), lipoteichoic acids (TLR-2/4), CpG DNA (TLR9), flagellin (TLR5) and others (reviewed in refs 4-6). This sensing initiates an intracellular signaling cascade that culminates in the activation of a variety of proinflammatory and immune response genes. ${ }^{1,6}$ Proinflammatory cytokines provide augmentary signals through the upregulation of co-stimulatory and adhesion molecules, which are essential for the activation of adaptive immune cells and the subsequent development of protective immune responses against the infectious nonself antigens. ${ }^{7,8}$ In recent years, a number of microbial components have been used as adjuvants to augment the immune responses of poorly immunogenic vaccines. Even though all the adjuvants studied so far have proven to be effective, flagellin, a TLR5 agonist, has been shown more promising results without any major side effects.

Flagellin is the structural component of the flagellum, a locomotory organ that is mostly associated with Gram-negative bacteria. It is characterized by highly conserved $\mathrm{N}$ - and C-terminal domains (D1 and D2 domains) with an intervening hypervariable region (D3). ${ }^{9}$ Earlier, flagellin was viewed as a virulence factor in the context of motility rather than having a role in immune stimulation. The first report of the proinflammatory role of flagellin came from the in vitro studies of Ciacci-Woolwine et al. ${ }^{10}$ and Wyant et al., ${ }^{11}$ and their studies demonstrated that Salmonella flagellin is a potent inducer of cytokines in a pro-monocytic cell line at sub-nanomolar concentrations. Later, McDermott et al. ${ }^{12}$ reported that induction of the proinflammatory response in monocytes involves a high-affinity interaction between flagellin and the surface receptor present on innate immune cells. This surface receptor, which is responsible for the inflammatory and innate immune activity of flagellin, was demonstrated to be TLR5 by Hayashi et al., ${ }^{13}$ and it was subsequently confirmed by many other researchers. Further studies showed that recombinant proteins lacking the hypervariable region did not present the compromised adjuvant activity of flagellin; thus, these results indicate that the D1 and D2 domains are essential for the recognition of TLR5 and are sufficient to induce a proinflammatory response. ${ }^{14,15}$ The adjuvant potential of flagellin was first reported by Arnon and co-workers, ${ }^{16-18}$ and it was accordingly tested for adjuvant activity in combination with a number of bacterial, viral or parasitic antigens over the past

${ }^{1}$ Department of Public Health, College of Veterinary Medicine, Chonbuk National University, Iksan, Republic of Korea and ${ }^{2}$ Department of Medicine, College of Medicine and Life Sciences, University of Toledo, Toledo, OH, USA

Correspondence: Professor JH Lee, College of Veterinary Medicine, Chonbuk National University, Iksan 54596, Republic of Korea.

E-mail: johnhlee@jbnu.ac.kr

Received 7 December 2016; revised 23 April 2017; accepted 1 May 2017 


\section{Table 1 Flagellin as an adjuvant}

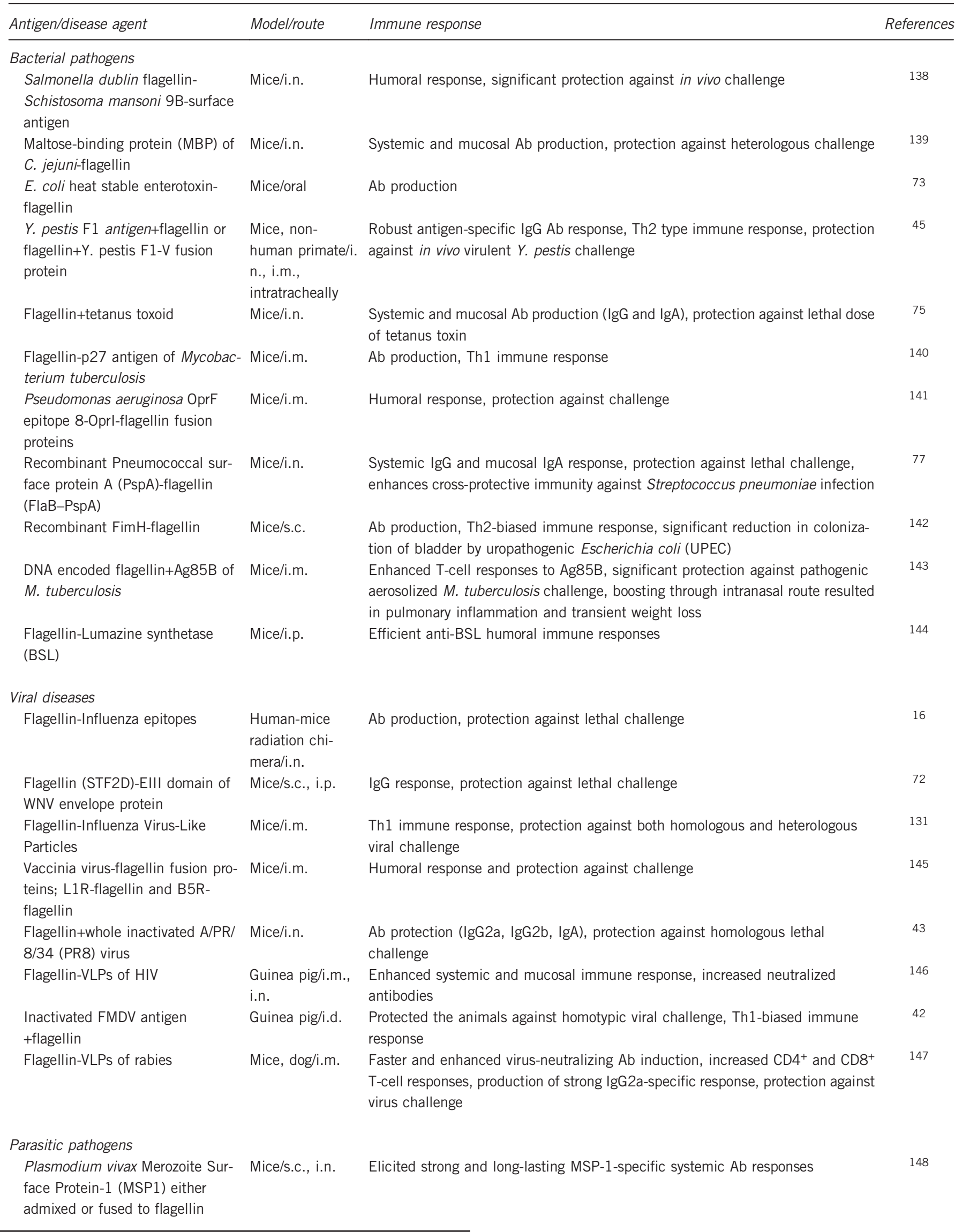


Table 1 (Continued)

\begin{tabular}{|c|c|c|c|}
\hline Antigen/disease agent & Model/route & Immune response & References \\
\hline $\begin{array}{l}\text { Recombinant Flagellin- } \\
\text { circumsporozoite (CS) peptide of } \\
\text { Plasmodium yoelii or flagellin } \\
\text { +synthetic peptide }\end{array}$ & Mice/oral & Elicitation of $\mathrm{CS}$ peptide-specific $\mathrm{CD}^{+} \mathrm{T}$ cells & 149 \\
\hline $\begin{array}{l}\text { Recombinant malarial CS protein } \\
\text { (MSP-119)-C-terminal end of FliC }\end{array}$ & Mice, rabbit/s.c. & $\begin{array}{l}\text { Systemic Ab production, Th2-biased immune response, antibodies inhibit in vitro } \\
\text { growth of the parasite }\end{array}$ & 79 \\
\hline $\begin{array}{l}\text { Recombinant immune mapped } \\
\text { protein-1 (IMP1) of Eimeria } \\
\text { tenella-truncated FliC }\end{array}$ & Poultry/i.m. & Stronger cellular immune responses, reduced oocyst output and cecal lesions & 150 \\
\hline \multicolumn{4}{|l|}{ Miscellaneous agents } \\
\hline Flagellin-EGFP fusion protein & Mice/s.c. & Antigen-specific T-cell responses & 151 \\
\hline $\begin{array}{l}\text { Flagellin-OVA fusion protein } \\
\text { (STF2.OVA) }\end{array}$ & Mice/s.c. & IgG1 and IgG2a responses, $\mathrm{CD} 8^{+} \mathrm{T}$-cell response & 152 \\
\hline $\begin{array}{l}\text { Chitosan-DNA nanoparticles carry- } \\
\text { ing flaA gene of } C \text {. jejuni }\end{array}$ & $\begin{array}{l}\text { White } \\
\text { Leghorn/i.n. }\end{array}$ & $\begin{array}{l}\text { Systemic and mucosal Ab production, protection against homologous challenge, } \\
\text { significantly reduced bacterial load in intestines }\end{array}$ & 76 \\
\hline $\begin{array}{l}\text { Lyophilized plant powder contain- } \\
\text { ing flagellin +OVA }\end{array}$ & Mice/oral & Systemic and mucosal $\mathrm{Ab}$ response, mixed Th1 and Th2 response & 93 \\
\hline DNA encoded flagellin+OVA & $\begin{array}{l}\text { Mice/i.d., } \\
\text { i.m., i.n. }\end{array}$ & Systemic and mucosal antibody production and Th1 response & 153 \\
\hline $\begin{array}{l}\text { Flagellin displaying cocaine hap- } \\
\text { ten, GNE }\end{array}$ & Mice/s.c. & Dose-dependent stimulation of anti-GNE Ab production & 154 \\
\hline
\end{tabular}

Abbreviations: Ab, antibody; i.d., intradermal; i.n., intranasal; i.m., intramuscular; i.p., intraperitoneal; s.c., subcutaneous.

two decades (Table 1). The incorporation of flagellin as an adjuvant has produced safe, potent vaccines, and some of the vaccines eventually made their way into human clinical trials. ${ }^{19,20}$ More significantly, flagellin has also been examined for anti-tumor and radioprotective activities and has shown tremendous potential in combating tumor growth and radiation-associated tissue damage; some flagellin-based antitumor vaccines have successfully entered into human clinical trials (Table 2).

\section{FLAGELLIN SENSING BY IMMUNE AND NON-IMMUNE CELLS}

Flagellin activates immune and non-immune cells via the germ line-encoded pattern recognition receptor TLR5. ${ }^{15,21}$ TLR5 possesses three structural domains, namely, extracellular leucine-rich repeats, transmembrane region and TIR domain. ${ }^{3}$ The TLR5 recognition of flagellin involves a set of relatively conserved amino-acid residues present on both the $\mathrm{N}$ - and C-terminal domains of flagellin. ${ }^{22}$ Like other TLRbound complexes, the flagellin-bound TLR5 forms a symmetric $\mathrm{m}$-shaped dimer that mediates dimerization of the intracellular TIR domains, which is essential for the activation of downstream pathways. Flagellin-induced dimer formation involves amino-acid residues 12 and 13 from the LLRs of TLR5, which are critical for TLR5 activity, as mutations in these LLRs result in forms of TLR5 that fail to transcriptionally activate the NF$\kappa \mathrm{B}$ reporter system. ${ }^{22}$ Furthermore, the TIR domain is important for downstream signaling, as a single point mutation in this domain abolishes TLR5 activity. ${ }^{23}$
TLR5 is present on a variety of cells, including monocytes, macrophages, neutrophils, lymphocytes, NK cells, dendritic cells (DCs), epithelial cells and lymph node (LN) stromal cells. $^{21,24,25}$ It is highly expressed in gut, especially in lamina propria DCs, ${ }^{26}$ where it controls the composition of the microbiota. ${ }^{27}$ The interaction of flagellin with TLR5 results in the induction of a variety of gene expression, including proinflammatory cytokines, nitric oxide (NO), $\mathrm{H}_{2} \mathrm{O}_{2}$, chemokines and host-defense proteins. ${ }^{3,27,28}$ Flagellin activates TLR5expressing cells either through MyD88-dependent or -independent pathways. MyD88-dependent stimulation recruits downstream adapter molecules that activate the MAP and IkB kinase pathways, leading to the induction of transcription factors AP-1 and NF- $\mathrm{B}$, respectively, which subsequently activates a variety of genes that are important for host-defense (Figure 1). ${ }^{27,29}$ The MyD88-independent pathway involves the formation of a TLR5/TLR4 heterodimeric complex that activates cells through the TRIF-mediated pathway instead of the MyD88 adapter molecule. TRIF activation induces the production of antiviral cytokine IFN- $\beta$ via the IRF3 transcription factor. Subsequently, IFN- $\beta$ results in the activation of the STAT1 transcription factor, which promotes inducible NO synthase ( $i$ NOS) gene transcription and $\mathrm{NO}$ production (Figure 1). ${ }^{30}$

Certain Gram-negative bacteria, such as Salmonella, translocate flagellin into the host cell cytoplasm via a type III secretory system. ${ }^{31}$ Type III secretory system is a very common virulence factor utilized by Gram-negative bacteria to facilitate the translocation of effector proteins, such as flagellin, into the cytoplasm of host cells to exert control over distinct host cell 
Table 2 Flagellin as an anti-tumor agent

\begin{tabular}{|c|c|c|c|}
\hline Treatment & $\begin{array}{l}\text { Model/ } \\
\text { route }\end{array}$ & Effect & References \\
\hline $\begin{array}{l}\text { Flagellin+D2F2 } \\
\text { tumor cells }\end{array}$ & Mice/s.c. & $\begin{array}{l}\text { Increased IFN- } \gamma / \mathrm{IL}-4 \text { ratio, decreased frequency of Treg cells, significant reduction of tumor growth, CD8 } \\
\text { cytotoxic immune response }\end{array}$ & 103 \\
\hline $\begin{array}{l}\text { Flagellin+CpG } \\
\text { motifs }\end{array}$ & Mice/s.c. & Promoted Th1 polarization, synergism between TLR5 and TLR9, complete remission of tumor growth & 103 \\
\hline $\begin{array}{l}\text { Flagellin } \\
\text { treatment }\end{array}$ & Mice/i.p. & Protection against radiation, induction of radioprotective genes & 27 \\
\hline $\begin{array}{l}\text { TLR5 activation } \\
\text { on breast cancer } \\
\text { cells }\end{array}$ & $\begin{array}{l}\text { Mice/i.v., } \\
\text { mammary } \\
\text { fat pads }\end{array}$ & $\begin{array}{l}\text { Neutrophil infiltration in vivo, increased autophagy protein MAP1S in cancer cells, autophagy of cancer } \\
\text { cells, inhibited tumor growth in vivo }\end{array}$ & 155,156 \\
\hline $\begin{array}{l}\text { Salmonella enter- } \\
\text { itidis serovar } \\
\text { Typhimurium } \\
\text { infection }\end{array}$ & In vitro & Apoptosis of adenocarcinomic human alveolar basal epithelial cells A549 in vitro & 157 \\
\hline $\begin{array}{l}\text { Flagella-based } \\
\text { MUC1 vaccines }\end{array}$ & $\begin{array}{l}\text { Balb/c, or } \\
\text { human } \\
\text { MUC1 } \\
\text { transgenic } \\
\text { mice }\end{array}$ & $\begin{array}{l}\text { Flagellin increased higher efficiency of therapeutic activity of MUC1-based vaccines, significant reduction in } \\
\text { size and growth rate of the tumor, lowered number of metastases, expanded life span of vaccinated mice }\end{array}$ & 158 \\
\hline $\begin{array}{l}\text { Flagellin+glu- } \\
\text { cose-regulated } \\
\text { protein } 170 \\
\text { (Grp170) }\end{array}$ & Mice & Protection against melanoma, colon and prostate cancer, induction of potent $\mathrm{CD}^{+} \mathrm{T}^{+}$-cell responses & 109 \\
\hline $\begin{array}{l}\text { Flagellin+E6/E7 } \\
\text { peptide of } \\
\text { papillomavirus }\end{array}$ & Mice/s.c. & Elicitation of tumor-specific IFN- $\gamma$ producing $\mathrm{CD}^{+} \mathrm{T}$ cells, retarded in vivo tumor growth, prolonged survival & 117 \\
\hline $\begin{array}{l}\text { Flagellin-derived } \\
\text { TLR5 agonist, } \\
\text { CBLB502 }\end{array}$ & Mice/i.v. & $\begin{array}{l}\text { Protected mice from tumor death, increased NK cell and CD8 }{ }^{+} \text {cytotoxic activities, clinical trial in patients } \\
\text { with advanced solid tumors is currently ongoing }\end{array}$ & 111 \\
\hline $\begin{array}{l}\text { Flagellin+P10 } \\
\text { peptide of Para- } \\
\text { coccidioides } \\
\text { brasiliensis }\end{array}$ & Mice/i.n. & $\begin{array}{l}\text { Activation of tumor-specific CD4 }{ }^{+} \text {T lymphocytes, marked reduction of lung nodules, significant increase in } \\
\text { survival, protection against metastatic melanoma growth after adoptive transfer }\end{array}$ & 159 \\
\hline
\end{tabular}

Abbreviations: i.n., intranasal; i.p., intraperitoneal; i.v., intravenous; s.c., subcutaneous.

signaling pathways. ${ }^{31}$ The delivery of flagellin in the host cell cytoplasm is first recognized by the NAIP (NLR family, apoptosis inhibitory protein) family proteins NAIP5 and NAIP6. ${ }^{32}$ Subsequently, the flagellin-bound NAIP5/6 complexes interact with NOD-like receptor NLRC4, resulting in the activation of caspase- 1 , which cleaves pro-interleukin- $1 \beta$ into active IL-1 $\beta$, a potent proinflammatory cytokine that is crucial for host-defense responses to infection and injury. ${ }^{33,34}$ While the conserved $\mathrm{N}$ - and C-terminal domains of flagellin are required for TLR-binding activity, the recognition of flagellin by NLRC4 seems to involve the $35 \mathrm{C}$-terminal amino acids of flagellin, as mutations of specific leucine residues in the C-terminal domain abrogate NAIP5/NLRC4-mediated inflammasome formation. ${ }^{35,36}$

Flagellin is also recognized by plant cells via flagellin sensing 2 (FLS2), which is a leucine-rich repeats receptor kinase and a homolog of TLR5.$^{37}$ FLS2 interacts only with the linear motif in the N-terminal of flagellin, whereas TLR5 interacts with both the $\mathrm{N}$ - and C-terminal domains. The recognition of flagellin by FLS2 results in the rapid phosphorylation of MAP kinase pathway, which subsequently culminates in the production of host-defense proteins that mediate protection against fungal and bacterial infections ${ }^{37,38}$ (Figure 2). Bacterial flagellin is also recognized by the FLS3 receptor in certain solanaceous plants, including tomato, potato and pepper. ${ }^{39}$ FLS3 recognizes flgII-28, a region of bacterial flagellin that is distinct from the region perceived by the FLS2 receptor, and enhances immune responses that protect leaf tissues against bacterial colonization. ${ }^{39}$ Certain plant pathogens have evolved to evade FLS2-mediated immunity; thus, transfer of the FLS3 receptor to other crop plants might offer the potential to mediate protection against pathogens that have evolved to evade FLS2mediated immunity. ${ }^{39}$

In addition to TLR5, flagellin is also recognized by TLR11, a recently discovered PRR present in mice. ${ }^{40}$ The interaction of flagellin with TLR11 is more restricted compared to its 
interaction with TLR5. A study by Hatai et al. ${ }^{40}$ shows that TLR5 strongly interacts with flagellin at both acidic and neutral $\mathrm{pH}$ conditions, whereas acidic conditions are essential for TLR11-flagellin interactions. Furthermore, this study shows that both the $\mathrm{N}$ - and C-terminal domains of flagellin can independently interact with TLR11, whereas the TLR5-flagellin interaction requires both domains to mediate a proinflammatory cytokine response and thus adjuvant activity. ${ }^{14}$ TLR11 is highly expressed in epithelial cells in various organs, such as intestine, lung and skin, and it has a role in the prevention of Salmonella invasion in mice. ${ }^{41}$ This result is in contrast to TLR5-deficient mice, which show enhanced resistance against oral Salmonella infection. ${ }^{26}$ These findings clearly suggest that flagellin-TLR11 signaling mechanisms differ from flagellinTLR5 interactions, and therefore, active research is needed in this regard.

\section{HOW DOES FLAGELLIN CONTRIBUTE TO THE ADJUVANTICITY OF VACCINES?}

Flagellin has shown tremendous potency as an adjuvant, either in the context of a fusion protein or by co-administration with antigens. ${ }^{19,20,42,43}$ The presence of TLR5 on a number of innate and adaptive immune cells might form the basis of its adjuvant activity (Figure 3). Most of the adjuvants, including TLR agonists, mediate their activity, in part, by activating the innate immune system, including DC activation, maturation and recruitment to T-cell areas in the LNs. ${ }^{44}$ Flagellin is a potent activator of both the innate and adaptive immune system. Studies have demonstrated that the dose of flagellin required to promote a maximal antigen-specific antibody response is relatively less than the dose required to stimulate maximal innate immune responses, ${ }^{29,45}$ suggesting that the induction of an antibody response is not linearly dependent on the strength of an innate immune response. This result is most likely due to the ability of flagellin to stimulate the induction of proinflammatory cytokines and chemokines in a number of innate and non-immune cells, including DCs, NK cells, epithelial cells and LN stromal cells, ${ }^{24,25,46,47}$ which is critical for the activation and development of antigen-specific adaptive immune responses. The administration of flagellin or flagellin-based vaccines has also been shown to rapidly achieve a higher concentration in draining LNs, which therefore activates DCs and non-immune cells, such as epithelial and LN stromal cells. $^{47,48}$ The activation of these cell types by flagellin or flagellin-based vaccines leads to the induction of cytokines and chemokines, which promote a marked recruitment in $\mathrm{T}$ and $\mathrm{B}$ lymphocytes to draining $\mathrm{LNs},{ }^{29,49}$ and thus maximizes the chances of antigen-specific lymphocytes encountering their cognate antigens. These mechanisms reasonably contribute to the overall potency of flagellin-based vaccines.

The interaction of flagellin with DCs is either direct or indirect, depending on the type of DC involved; for instance, myeloid-derived DCs respond directly to flagellin through TLR5, while splenic DCs respond indirectly to flagellin and are most likely activated through a bystander process that requires the stimulation of other TLR5-expressing cells. ${ }^{50-52}$
There are also indications that the effect of flagellin is dependent on the immunological site involved as, unlike splenic DCs, DCs in lamina propria respond directly to flagellin. ${ }^{53}$ There are many discrepancies in the literature regarding the interaction of flagellin and DCs in different species. Some investigators showed the stimulatory effect of flagellin on murine bone marrow-derived DCs, ${ }^{24,25,54,55}$ while others reported an effect on human myeloid-derived DCs, but not murine DCs. ${ }^{56}$ This variation in responses might be due to a number of factors (reviewed in ref. 47). The quality of flagellin also influences the outcome of experimental results. Recombinant flagellin, if used as an adjuvant, should be free of any endotoxins or nucleic acids as they activate the DCs in a TLR5-independent manner. In addition, long-term storage of some fusion proteins causes molecular aggregation, which activates cells in a TLR5-independent manner, as has been reported with the polymeric flagellin that directly stimulates B cells. ${ }^{57}$ The ability of cells to respond to flagellin also depends on the state of differentiation. The pretreatment of innate immune cells with GM-CSF and IL-4 makes them more responsive to flagellin as compared to untreated cells. ${ }^{10,47}$ Flagellin of different bacterial species also varies in immunogenicity, ${ }^{43}$ and not all bacterial flagellins activate TLR5. ${ }^{58}$ In contrast to the flagellins of $\gamma$-proteobacteria, flagellins from the $\varepsilon$-proteobacteria Campylobacter jejuni and Helicobacter pylori do not activate TLR5 signaling and thus can evade TLR5-mediated immune surveillance at mucosal surfaces. ${ }^{58}$ This difference, in part, might be attributed to the structural differences among the flagella of different microbes; for instance, flagellin of $C$. jejuni consists of 7 protofilaments instead of the 11 found in the $\gamma$-proteobacteria Salmonella, which contains highly conserved residues between the protofilaments that are involved in the TLR5 interaction. ${ }^{59,60}$ The functional differences between TLR5-activating flagellins and non-activators might also be attributed to sequence variations among the flagellins of bacteria species. For instance, the hot spot residues (residues 89 and 114) on the flagellins of $\gamma$-proteobacteria that make complementary contacts with TLR5 are replaced with threonine and aspartate residues, respectively, in C. jejuni and H. pylori flagellins. Thus, C. jejuni and $H$. pylori flagellins might fail to make complementary contacts with TLR5 and subsequently fail at TLR5 activation. ${ }^{61}$

Another factor that contributes to the adjuvant activity of flagellin is the presence of TLR5 on the cells of the adaptive immune system, T and B cells. Flagellin directly influences the phenotype and functions of these cells, and thereby directly regulates the adaptive immune system. Most of the studies in humans have shown that flagellin directly activates $\mathrm{T}$ cells and is equivalent to anti-CD28 in stimulating the proliferation of T cells. ${ }^{62,63}$ A study by Means et al. ${ }^{56}$ shows that flagellin-treated DCs have a slightly lower stimulatory T-cell effect than LPS-treated DCs, and flagellin stimulation induces the expression of chemokines GRO- $\alpha$, GRO- $\beta$, GRO- $\gamma$, IL-8, MCP-1, MIP-1 $\alpha$, MIP-1 $\beta$ and RANTES in DCs. The induction of these chemokines is very rapid and occurs even before the expression of homing chemokine receptors, thereby recruiting 


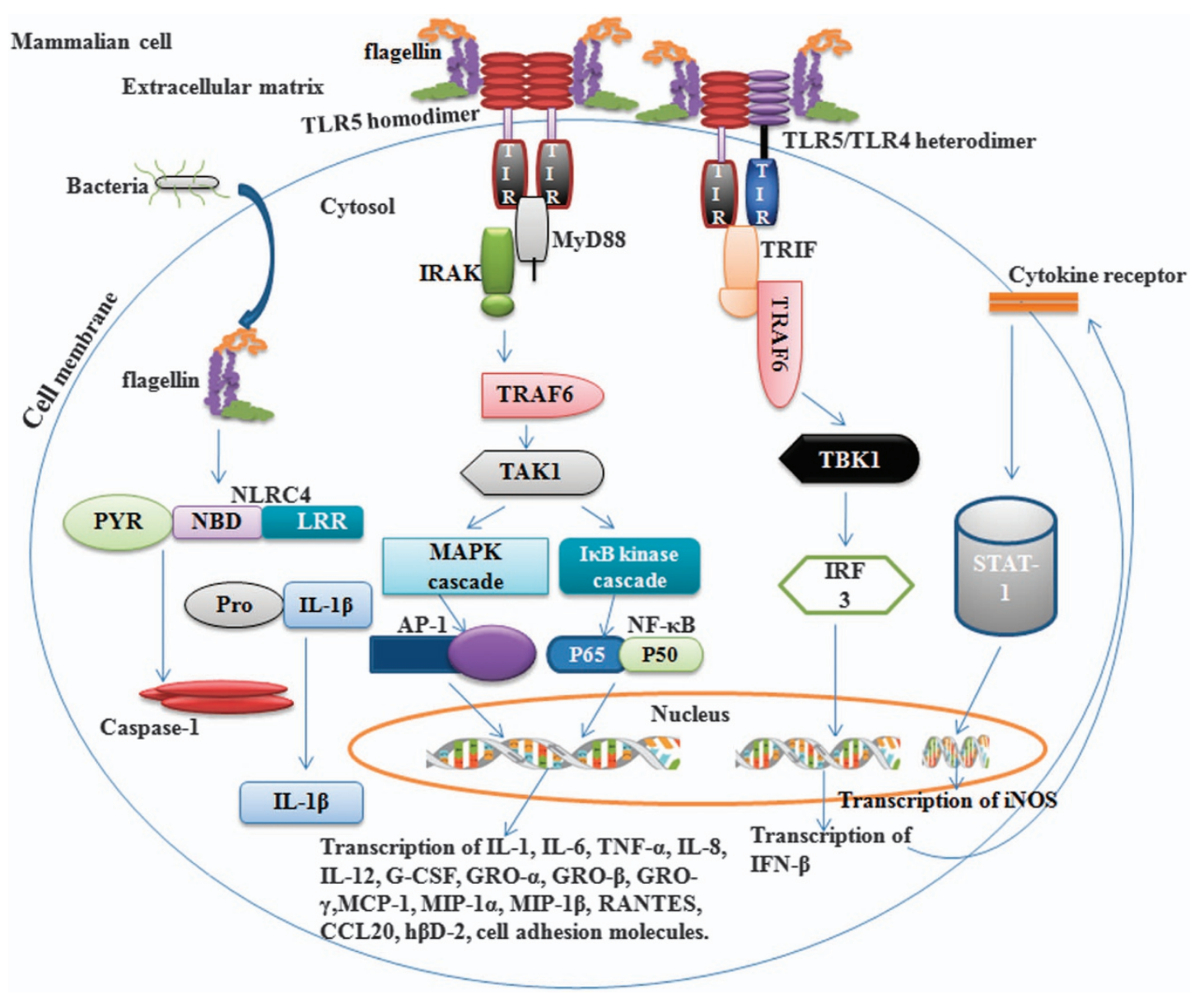

Figure 1 Signal transduction by flagellin in mammalian cells. Immune cells respond to extracellular monomeric flagellin through either TLR5 homodimer or heterodimer complexes, resulting in the transcription of a variety of genes that are important for the proper stimulation of immune cells. Signaling through TLR5 occurs through a MyD88-dependent adapter molecule that passes the signal to the MAPK and IkB cascades via IRAK, TRAF6 and TAK1. The MAPK and IkB cascades result in the induction of transcription factors AP-1 and NF-kB, respectively. These two transcription factors induce a variety of genes involved in innate and adaptive immunity. Signaling through TLR5/ TLR4 is MyD88-independent and occurs via the IRF3 pathway, which results in the production of IFN- $\beta$. Subsequently, IFN- $\beta$ induces iNOS gene transcription through the activation of STAT1, which culminates in the production of NO. However, when intracellular flagellin is introduced into the host cell cytoplasm via the type III secretory system by some bacteria, it is detected by NLRC4, which culminates in the secretion of IL-1 $\beta$ via active caspase-1. AP-1, Activator protein-1; GRO, growth-related oncogene; hBD, human beta defensins; IRF3, interferon response factor 3; IRAK, IL-1 receptor associated kinase; LRR, leucine-rich repeats; MAPK, mitogen-activated protein kinase; MCP, monocyte chemoattractant protein; MIP, macrophage inflammatory protein; MyD88, myeloid differentiation factor 88; NBD, nucleotide-binding domain; NF-кB, nuclear factor 'kappa-light-chain-enhancer' of activated B cells; PYR, pyrin domain; TAK1, transforming growth factor-beta-activated kinase 1; TBK1. TANK-binding-kinase-1; TLR, Toll-like receptor; TRAF6, TNF receptor associated factor 6; TRIF, TIR domain containing adapter inducing interferon- $\beta$; STAT1, signal transducer and activator of transcription 1.

lymphocytes to the secondary lymphoid sites. This outcome indicates that flagellin not only stimulates adaptive immune responses, but also recruits innate immune cells to the sites of infection or immunization. Thus, flagellin activates $\mathrm{T}$ cells in two ways: one is direct activation of T cells and the other is via presentation of the cognate antigen by antigen-presenting cells.

Flagellin also activates $\mathrm{T}$ regulatory cells (Tregs), which are potent suppressors of T-cell responses and possess higher levels of TLR5 than $\mathrm{CD} 4^{+} \mathrm{CD} 25^{-} \mathrm{T}$ cells. ${ }^{63}$ However, flagellin may simultaneously inhibit TCR-mediated Treg activation via a suppressor of the cytokine signaling 1-dependent mechanism, ${ }^{64}$ albeit these studies are currently lacking in the literature. Thus, the contribution of flagellin-mediated Treg activation and suppressor of the cytokine signaling 1-dependent regulation in the overall adjuvant potential of flagellin-based vaccines warrants further studies.

$\mathrm{B}$ cells are directly activated by flagellin through either cross linking of BCRs or signaling through TLR5, depending on the form of flagellin that is involved. B cells require TLR5 signaling, in addition to $\mathrm{T}$-cell help, for T-dependent antibody production ${ }^{65}$ or production can occur in presence of cytokines, such as TNF- $\alpha .{ }^{66}$ Monomeric flagellin activates TLR5 signaling in B cells and promotes a long-lasting, T-dependent antibody response. In contrast, polymeric flagellin directly stimulates $\mathrm{B}$ cells by cross linking $\mathrm{BCRs}^{57}$ and generates antibody responses of the IgM type without the help of $\mathrm{T}$ cells. 


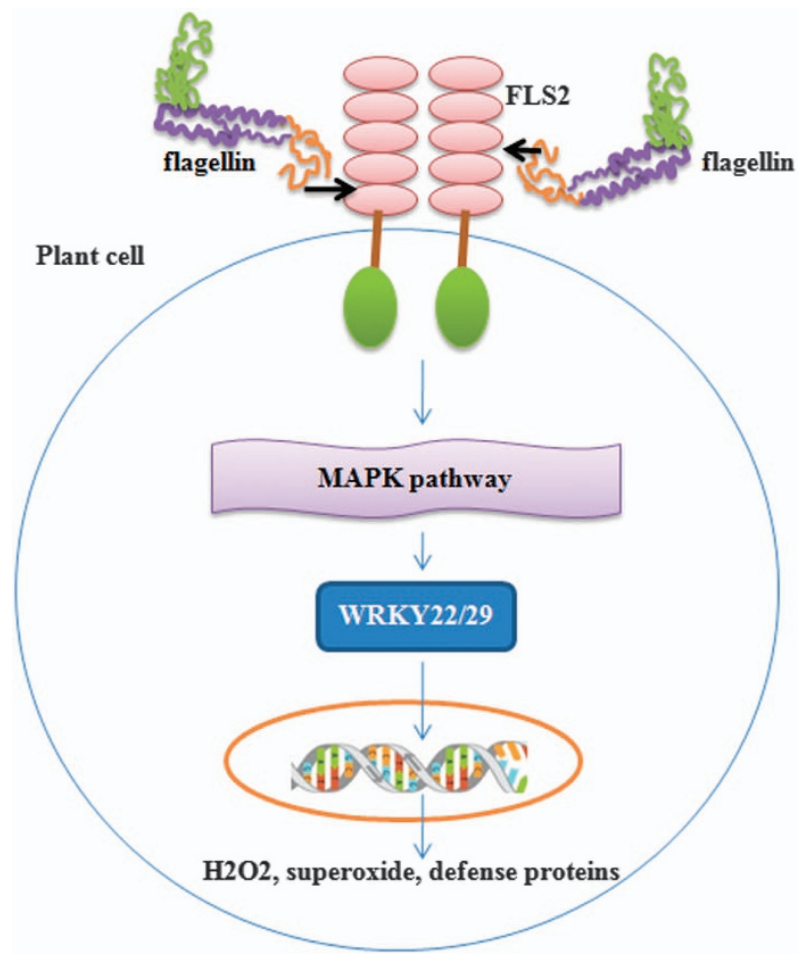

Figure 2 Signal transduction by flagellin in plant cells. Plant cells also possess receptors similar to TLR5 called flagellin sensing receptors (FLS2). FLS2 interact with the linear motif of flagellin in the $\mathrm{N}$ terminus (shown by arrow), which results in the rapid induction of a phosphorylation cascade of MAP kinases. MAPKs, in turn, activate the transcription factor WRKY22/29, which induces the transcription of genes providing resistance against fungal and bacterial infections. Due to differences in the homology of LLRs in TLR5 and FLS2, the flagellin-interacting motifs are different in these species.

Furthermore, flagellin also promotes class switching in B cells, thus generating more potent and diverse antibody responses. ${ }^{67}$ In addition to TLR5, the recognition of flagellin by inflammasomes (NLRC4) also plays an important role in the generation of antibody responses, and either TLR5 or inflammasome (NLRC4) is necessary and sufficient for the production of humoral immunity. ${ }^{68}$ However, López-Yglesias et al. ${ }^{69}$ reported that anti-flagellin IgG1 antibody responses develop through TLR5- and inflammasome-independent pathways, suggesting that other receptors or distinctive pathways are involved in the generation of humoral responses. The elucidation of other pathways of recognition will clearly contribute to a better understanding of flagellin-host interactions and will be critical for the rational design of flagellin-based vaccines.

\section{FLAGELLIN AS A MUCOSAL ADJUVANT}

The administration of vaccines through the mucosal route is an attractive idea, albeit the adjuvants that elicit robust immune responses at mucosal surfaces are lacking. The presence of TLR5 on epithelial cells, which are often the first major cell types to encounter infectious and non-infectious agents, might form the basis for prospects of flagellin as a mucosal adjuvant. ${ }^{29,51}$ The elicitation of immune responses at mucosal surfaces through the use of flagellin has the potential to eradicate or at least prevent the bad outcome of diseases. During the past two decades, flagellin has been extensively tested as a mucosal adjuvant against epitope-based influenza vaccines, ${ }^{19,20,70,71}$ West Nile virus (WNV), ${ }^{72}$ Escherichia coli, ${ }^{73}$ Yersinia pestis, ${ }^{45,74}$ Clostridium tetani, ${ }^{75}$ C. jejuni, ${ }^{76}$ Streptococcus ${ }^{77}$ and Plasmodium falciparum. ${ }^{78,79}$

The induction of cytokines and chemokines is key to the adjuvant potential of flagellin. ${ }^{21,29}$ Flagellin is a more potent activator of epithelial cells than LPS and polarizes the response toward IL-8 secretion at epithelial surfaces. ${ }^{80-82}$ Eaves-Pyles et al. showed that flagellin causes rapid degradation of $I \kappa \mathrm{B} \alpha$, the inhibitor of NF- $\mathrm{BB}$, in epithelial cells, and induces a variety of proinflammatory mediators, including NO, IL-6, IL-8, CXCL2 and cytoprotective genes. ${ }^{80,83,84}$ These mediators play an important role in the activation of innate and adaptive immune responses at mucosal surfaces, ${ }^{85,86}$ thus mediating protection against the intruding pathogens. NO enhances IgA class switching and production by upregulating TGF $\beta$ RII expression on B cells and by inducing the expression of BAFF and APRIL in DCs. ${ }^{86,87}$ Moreover, NO and CXCL2 play an important role in the activation and recruitment of professional antigen-presenting cells at a vaccinal or tissue injury site, ${ }^{85}$ where they pick up and transport the foreign antigens to the draining LNs for presentation of the processed antigens to the $\mathrm{CD}^{+} \mathrm{T}$ cells, which is essential for the development of effective antigen-specific immune responses. ${ }^{88}$ Furthermore, these mediators recruit neutrophils and professional killer cells at mucosal surfaces, ${ }^{85}$ thus providing nonspecific protection against the intruders.

The cytokine IL-6 helps in the development of effective and potent mucosal immune responses and protects the host against bacterial and viral infections. ${ }^{89}$ Flagellin is the major determinant in Crohn's disease, a chronic intestinal disorder caused by inappropriate immune responses to commensal intestinal microflora generated by the interaction of TLR5 present on the epithelial cells and flagella in the intestinal milieu. ${ }^{90}$ This implies that flagellin is a potent inducer of proinflammatory cytokines at mucosal surfaces and that it is sufficient to overcome oral tolerance, which is a major pitfall for the mucosal route delivery of vaccines. ${ }^{91}$ Flagellinadjuvanted vaccines administered through a mucosal route have been shown to elicit a strong antibody and cell-mediated immune responses, both at mucosal surfaces and at systemic level. ${ }^{77,92}$

Plant-expressed flagellin has proven potent adjuvant activity for orally administered antigens. ${ }^{93}$ A study by Girad et al. ${ }^{93}$ showed that orally administered, lyophilized plant powder containing plant-expressed flagellin and ovalbumin induced ovalbumin-specific humoral and cell-mediated immune responses and thus prevented the occurrence of oral tolerance. All these findings clearly indicate that flagellin has a substantial potential to act as a mucosal adjuvant. In addition to its role in mucosal adjuvanticity, TLR5 also plays a role in controlling bacterial infections at mucosal surfaces. Hawn et al. ${ }^{94}$ reported 

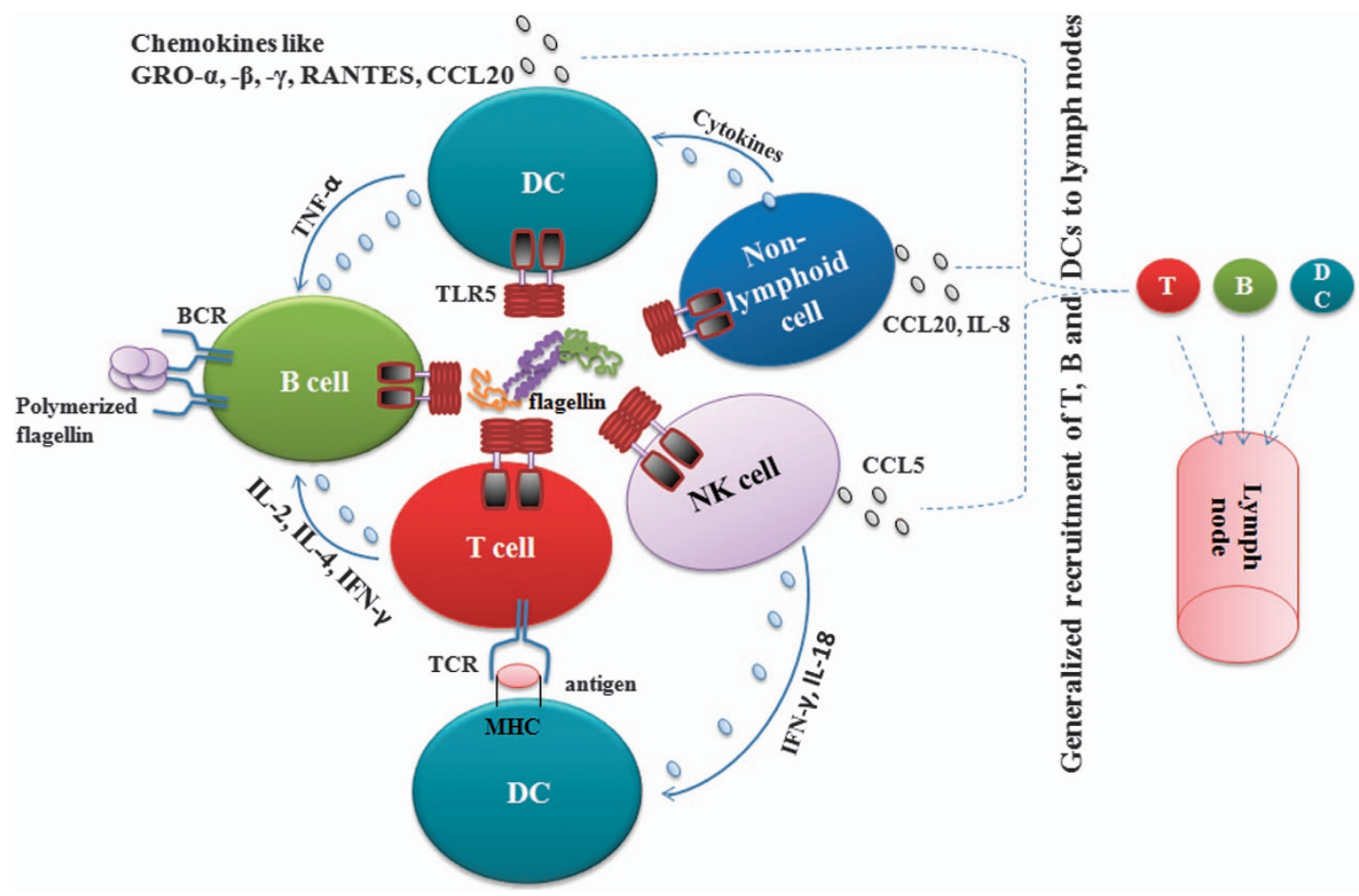

Figure 3 Flagellin interactions with different kinds of immune and non-immune cells. Flagellin directly activates a number of immune and non-immune cells, including T, B, DCs, NK and non-lymphoid cells (macrophages, epithelial, fibroblasts, stromal cells and neutrophils), through TLR5. The cumulative effect of this activation is the augmentation of immune responses through the generation of more potent antibodies and a Th1 response. Moreover, the interaction of flagellin with TLR5 culminates in the production of chemokines from a number of lymphoid and non-lymphoid cells, which results in the generalized recruitment of $T$ and $B$ cells to LNs, which maximizes the chances of an encounter with their cognate antigen and subsequent elicitation of potent immune responses. Instead of TLR5, polymerized flagellin directly stimulates B cells by cross linking BCRs, which might generate antibody responses of the IgM type.

that a common stop codon polymorphism in TLR5 in lung epithelial cells abolishes flagellin activity and increases the incidence of human lung infections by flagellated bacteria. This case signifies that TLR5 have an innate immune regulatory role in lung epithelial cells as well.

\section{FLAGELLIN AS AN ANTI-TUMOR AGENT}

TLR agonists have also been tested for anti-tumor activity in animal models and some of them have eventually made their way into human clinical trials (reviewed in refs 95-97). The immunobiology of TLRs in tumor progression or regression is very intricate and complex. Some studies show that activation of TLR4 or TLR9 on cancer cells promotes tumor progression and growth, ${ }^{98-100}$ whereas others show that TLR3 and TLR5 activation exhibits inhibitory effects. ${ }^{101,102}$ Among TLR agonists, the effect of flagellin is unique, as it does not involve the innate arm of immunity in combating tumor growth but rather is entirely dependent on the activation of adaptive immunity. ${ }^{103}$ Sfondrini et al. ${ }^{103}$ reported that administration of purified flagellin at the time of tumor transplantation enhanced tumor growth, whereas the same flagellin resulted in the regression of a palpable tumor. This finding can be explained by way of the immune bias induced by flagellin in response to weak or highly immunogenic tumors. The interaction of flagellin with highly immunogenic tumors induces a Th1 response and suppression of Tregs, resulting in the inhibition of tumor growth. However, weakly immunogenic tumors polarize the response toward Th2, which prevents the apoptosis of Tregs and increases their suppressive effect on $\mathrm{CD}^{+}$Th1 cells, ${ }^{103,104}$ favoring tumor growth. This result also suggests that preactivated adaptive immunity is critical to the anti-tumor activity of flagellin. The combination of flagellin with CpG-ODN has been shown to abrogate the negative effect of flagellin on tumor growth and has produced a synergistic response in tumor inhibition. ${ }^{103}$ This might be due to induction of IL-12 and IL-23 expression in DCs and consequent Th1 bias, as has been reported with the combination of flagellin and other TLR agonists. ${ }^{105}$ Recently, Salmonella typhimurium has been used to express and secrete flagellin of Vibrio vulnificus as an anti-cancer agent against a variety of cancers in mouse models. ${ }^{106}$ This study shows that flagellinsecreting Salmonella targeted to the tumor microenvironment exerted potent tumoricidal activity through two-step activation of the TLR4 and TLR5 signaling pathways. The tumor suppressive effects of flagellin-secreting Salmonella were far more potent than those mediated by Salmonella harboring an empty vector, ${ }^{106}$ indicating synergistic effects of the TLR4 and TLR5 signaling pathways in combating tumor growth. In addition to the crosstalk between TLRs, Nod-like receptors (NLRs) inhibit tumor progression and act in concert with TLR5 to induce potent anti-tumor activity. A study by Garaude and Blander ${ }^{36}$ shows that engineered flagellin-bearing tumor 
cells elicit robust anti-tumor T-cell responses and tumor rejection in mice. This anti-tumor activity, mediated by flagellin, is dependent on the activation of both TLR5 and NAIP5, as abrogation of either NLR or TLR5 signaling restored the ability of flagellin-bearing tumor cells to form tumors in vivo and impaired immune responses, respectively. This explains why some TLR ligands tested as single adjuvants in phase II and III clinical trials failed at providing significant tumor regression. ${ }^{107}$ The crosstalk of TLR5 and NOD1 is supported by another study, which shows that combined stimulation of both the receptors strongly potentiates NF- $\kappa B$ activity, resulting in the elicitation of potent innate immune responses and protection against Salmonella infection. ${ }^{108}$ These findings clearly indicate the great potential for dual targeting of TLRs and NLRs in the design of optimal cancer vaccines.

Cancer immunotherapy aims to mount effective anti-tumor T-cell responses to control tumor growth and metastasis. Although this approach holds great promise for cancer treatment, its therapeutic application in chemotherapy has been limited so far. Despite the innate ability of the immune system to recognize tumor cells, several potential mechanisms are exploited by cancer cells to create an immunosuppressive environment that enables them to escape immune destruction. Thus, novel strategies should be employed to overcome immunosuppressive mechanisms and the induction of effective anti-tumor immunity. A study by $\mathrm{Yu}$ et al. ${ }^{109}$ shows that adenovirus expressing a fusion protein of flagellin and Grp170, the largest endoplasmic reticulum chaperone, induces a potent anti-tumor response against B16 melanoma and its distant lung metastasis compared to the co-administration of Grp170 and flagellin. The therapeutic potential of this treatment was also confirmed in mouse prostate cancer and colon carcinoma. ${ }^{109}$ The flagellin-Grp170 fusion resulted in the superior presentation of tumor antigens by DCs to $\mathrm{CD}^{+} \mathrm{T}$ cells, which subsequently elicited potent cytotoxic $\mathrm{CD}^{+} \mathrm{T}$-cell responses, both locally (that is, tumor site) and systemically. ${ }^{109}$ The tumor microenvironment can also be ameliorated to elicit anti-tumor responses through TLR5 ligand-secreting T cells, as reported by Kaczanowskaa and Davila. ${ }^{110}$ These studies suggest that targeting the tumor microenvironment with such novel strategies has great potential to overcome the immunosuppressive mechanisms of tumors and to induce effective anti-tumor immunity. Flagellin exclusively acts as a potent T-cell adjuvant to mediate anti-tumor immunity. Leigh et al. ${ }^{111}$ shows that a Salmonella flagellin-derived, pharmacologically optimized TLR5 agonist, CBLB502, stimulates robust anti-tumor activity through the direct activation of TLR5-expressing accessory immune cells, which subsequently stimulate cytotoxic $\mathrm{CD}^{+} \mathrm{T}$ cells. The antitumor potential of CBLB502 is further shown in another report. This report demonstrates that the strongest NF- $\mathrm{B}$ activation in response to CBLB502 occurs in the liver and GI tract, where liver hepatocytes and lamina propria DCs, respectively, are responsible for the primary CBLB502 response. ${ }^{112}$ CBLB205 agonist suppresses the liver metastases of different kinds of cancer regardless of their TLR5 status, indicating the activation of TLR5-bearing cells present in the tumor microenvironment, which in turn execute anti-tumor activity. ${ }^{112}$ To elucidate the exact role of innate immune cells, especially NK and DCs, in mediating the anti-tumor potential of flagellin, Brackett et al. ${ }^{113}$ reported that the TLR5 agonist entolimod (formerly named CBLB502) mediates anti-tumor activity through the NK-dendritic-CD8 ${ }^{+} \mathrm{T}$-cell axis. Entolimod activates NF-кB-, AP-1- and STAT3-driven immunomodulatory signaling pathways specifically within the liver and rapidly induces chemokines, such as CXCL9 and -10, which recruit blood-borne CXCR3-expressing NK cells to the liver. ${ }^{113} \mathrm{NK}$ cell-driven activation of DCs results in the elicitation of potent $\mathrm{CD}^{+}$T-cell responses, which exert both the anti-metastatic effect of entolimod and the induction of tumor-specific memory responses. ${ }^{113}$ These findings clearly indicate the potential of TLR5 agonists as potent organ-specific immunoadjuvants, enabling efficient anti-cancer immunization that does not rely on the recognition of tumor-specific antigens. In contrast to the TLR5-negative environment outside of the liver, the tumor must bear the TLR5 receptor to mediate the antitumor activity mediated by flagellin.

The expression of TLR5 has been used as a novel predictive marker for the recurrence and survival of various types of cancers. ${ }^{114}$ The expression of TLR5 has been shown to increase in various types of cancers, such as in gastric and colorectal carcinogenesis. Rhee et al. ${ }^{115}$ reported that gastric carcinoma expresses high levels of TLR5 and that treatment with flagellin elicits a potent anti-tumor activity. Flagellin induces the activation and proliferation of DCs and fibroblasts through the degradation of apoptosis-inducing protein ${ }^{116}$ p27, while the activation of TLR 5 on carcinoma cells inhibits proliferation and anchorage-independent growth. The activation of separate signaling pathways by flagellin in different cell types clearly warrants further research. Nguyen et al. ${ }^{117}$ demonstrate that flagellin acts a potent adjuvant for E6/E7 proteins of human papillomavirus and induces a strong $\mathrm{CD} 8^{+} \mathrm{T}$-cell response, which suppresses tumor growth and prolongs survival. This flagellin-based anti-tumor therapeutic vaccine resulted in the complete remission of lung metastasis through the activation of $\mathrm{CD}^{+} \mathrm{T}$ cells, involving the MyD88-dependent pathway. Thus, flagellin exclusively acts as an adjuvant for $\mathrm{T}$ cells and has the potential to be used for anti-cancer immunotherapy, even for TLR5 non-expressing tumor cells.

\section{FLAGELLIN AS A RADIOPROTECTIVE AGENT}

In addition to being a potent immunomodulatory and anticancer agent, flagellin also possesses a radioprotective property that protects the host against ionizing radiation. Radiationinduced tissue toxicity remains a major challenge in the delivery of tumoricidal doses of intestinal irradiation. Several significant studies have demonstrated the radioprotective potential of flagellin. Vijay-Kumar et al. ${ }^{27}$ reported that systemic administration of flagellin protects mice against irradiation in a TLR5-MyD88 manner. This protection is mediated by the cells of the innate immune system, which release cytoprotective cytokines, such as G-CSF, a known radioprotectant. $^{118}$ The exploitation of flagellin as a 
radioprotective agent seems to be dependent on the time of the administration of flagellin and the dose of radiation. The administration of flagellin is beneficial up to $4 \mathrm{~h}$ following irradiation, whereas there is no beneficial effect following $24 \mathrm{~h}$ post irradiation. ${ }^{27}$ This indicates that the early activation of innate immune cells plays an important role in combating the adverse toxicity of radiations. Other studies have also reported the radioprotective potential of flagellin. Burdelya et al. ${ }^{119}$ reported the radioprotective activity of a TLR5 agonist, CBLB502, and demonstrated that a single injection of this drug before lethal total-body irradiation protected mice and rhesus monkeys from both gastrointestinal and hematopoietic acute radiation syndromes and prolonged survival. Improved survival is also observed after irradiation, but at lower radiation doses. This radioprotective property is dependent on the activation of NF- $\mathrm{KB}$ signaling pathway, which subsequently culminates in the production of anti-apoptotic proteins, scavengers of ROS and growth factors. These factors play an important role in CBLB205's protection against gastrointestinal and hematopoietic acute radiation syndromes. ${ }^{112,119}$ CBLB502 also induces additional prosurvival signals via the STAT3 and AP-1 signaling pathways, which are responsible for liver resistance to Fas-mediated apoptosis. ${ }^{112}$ Furthermore, CBLB502-treated mice show higher concentrations of G-CSF and IL-6 in blood, which are known stimulators of hematopoietic stem cells (G-CSF) and the thrombopoietic lineage of hematopoiesis (IL-6). ${ }^{112}$ The radioprotective potential of flagellin is also attributed to its ability to modify the recruitment and phenotype of macrophages. A study by Lacavé-Lapalun et al. ${ }^{120}$ shows that the administration of flagellin 3 days after irradiation is associated with the transition of macrophages from a primarily proinflammatory M1 to a more anti-inflammatory M2 phenotype. This transition of phenotype resulted in a notable decrease of the acute damaging effects of radiation by reducing the inflammatory response and enhancing epithelial repair. All these findings clearly suggest that flagellin and a flagellin-derived agonist could potentially improve/expand the therapeutic window of tumoricidal doses of irradiations and thus serve as a biological protectant in radiation emergencies.

\section{BENEFITS OF FLAGELLIN-BASED VACCINES}

Flagellin-based vaccines have the potential to provide protection against various insults, including radiation, chemicals and pathogens. Previously, LPS has been used as a protective agent against such challenges and as vaccine adjuvant, but only to a limited extent, as it induces sepsis and pulmonary lung inflammation, even at low doses. ${ }^{121,122}$ Furthermore, LPS is a poor activator of epithelial cells, ${ }^{123}$ which are often the first cells to encounter pathogens and chemicals, and hence it may not provide optimum protection. The expression of TLRs varies in various organs and thus its protection varies against various kinds of challenges. A study by Burdelya et al. ${ }^{112}$ demonstrates that treatment with a TLR5 agonist, CBLB205, but not with LPS, improves survival of mice infected with a lethal dose of S. typhimurium. This study further reports that in response to CBLB502 treatment, liver hepatocytes show the highest NF- $\kappa \mathrm{B}$ expression, while LPS-activated NF- $\kappa \mathrm{B}$ expression specifically occurs in the lungs, spleen and kidney; thus, these results make biological sense, as the liver is the primary site of Salmonella residence during infections. This indicates that the tissue specificity of TLR5 and TLR4 expression plays an important role in providing protection against different kinds of challenges and that LPS and flagellin may act as organspecific immunomodulators. The use of flagellin over LPS is advantageous. Flagellin and a flagellin-based TLR5 agonist are significantly less toxic than agonists of many other TLRs. ${ }^{27,112}$ Flagellin induces the non-pathologic profile of cytokines and mediates less of the adverse effects associated with LPS. ${ }^{112,124}$ Flagellin is a potent activator of epithelial cells and a generally poor activator of hemopoietic cells, such as macrophages and DCs, which mediate sepsis. ${ }^{21}$ Flagellin-induced TLR5 signaling in epithelial cells results in the upregulation of cytokines, cytoprotective genes and other host-defense genes, which provides nonspecific protection against a variety of challenges, including orally ingested chemicals and pathogens, such as Salmonella and rotavirus infections. ${ }^{27}$ There is also a report that flagellin treatment curtails the symptoms of allergy that are usually associated with an allergen. ${ }^{125}$ Flagellin also mediates protection against ionizing radiations, which cause damage to various organs, particularly rapidly dividing mucous membranes. A 2-h prior exposure of flagellin has been found to provide protection against radiation and thus can be used prophylactically at the time of nuclear disaster. ${ }^{27}$ Flagellin has also been shown to induce antibacterial gene expression and heat shock proteins, which equips epithelial cells to better address pathogens and radiation. ${ }^{126}$ A flagellin-based TLR5 agonist, entolimod (CBLB502), has been used to reduce the systemic toxicity of 5-fluorouracil, an anti-tumor chemotherapeutic drug, and has improved the integrity of intestinal tissue and has stimulated hematopoiesis following treatment. ${ }^{127}$ This indicates that flagellin or a flagellin-based agonist has the clinical potential to broaden the therapeutic window of genotoxic anti-tumor drugs. Therefore, approaches should include flagellin in therapies or prophylaxis to provide broadspectrum protection against various kinds of challenges.

One of the major concerns with use of protein-based adjuvants, such as flagellin, is the induction of antibody responses that might neutralize their adjuvant potential and diminish or suppress the immune response against the antigen on subsequent immunizations. Prior immunity to flagellin does not hamper antibody production against the antigen. ${ }^{17}$ Furthermore, Eaves-Pyles et al. ${ }^{14}$ reported that conserved regions of flagellin are sufficient to induce a proinflammatory response in immune cells. Thus, the anti-flagellin immune response could be minimized by using the conserved regions only. Moreover, the plasticity of flagellin allows the creation of fusion proteins without compromising the conformational epitopes. ${ }^{20}$ The foreign antigens can be physically linked to the $\mathrm{N}$ - or C-terminal or the hypervariable region can be replaced. Song et al. ${ }^{128}$ fused the HA globular head of H1N1 influenza virus to the C-terminal of flagellin, which protected 
mice against lethal challenge and was immunogenic and well tolerated in humans. In a subsequent study, they replaced the hypervariable region of flagellin with the HA globular head of H5N1 and found that it was more efficacious and immunogenic than the previous design. ${ }^{129}$ These influenza vaccines have elicited robust, long-lasting ( $>8$ month) neutralizing antibody responses, have protected mice against lethal challenges and are currently under clinical trials. ${ }^{129,130}$ Immunogenic antigens of other pathogens have also been fused to flagellin; for instance, fusion of the C-terminal end of merozoite surface protein-1 (MSP-119) with the C-terminal end of flagellin developed strong, specific and long-lasting antibody-mediated responses. ${ }^{79}$ The booster immunization showed that the immune response was similar to emulsified complete or incomplete Freund's adjuvanted vaccine. ${ }^{79}$

Flagellin has shown adjuvant potential both as a fusion protein or in its co-administration with an antigen without any physical linking. ${ }^{19,42,43}$ However, there is a minor discrepancy in the literature regarding the use of flagellin in the context of a fusion partner or in its co-administration with an antigen. Some studies have shown that the co-administration of flagellin with an antigen does not augment the immune response and therefore, physical linking of flagellin with an antigen is required for its adjuvant activity ${ }^{131}$ We and others have shown that there is no requirement for the physical linking of flagellin to the antigen and that co-administration generates potent immune responses. ${ }^{42,43,132}$ All these studies show that flagellin augments immune response manifolds and protects animals against a lethal challenge. Linking the antigen to flagellin might be a superior strategy due to the better activation of DC through TLR5 signaling, which provides a means for efficient antigen internalization and access to the antigen processing pathway. In addition, flagellin has the potential to act as an adjuvant of its own against one or more epitopes present in the hypervariable region. ${ }^{133}$

Most adjuvants are effective in young or middle-aged populations and are less efficient in older people, who are in dire need of good quality adjuvants or vaccines. Flagellin has shown effective adjuvant activity in aged mice and has enhanced antigen-specific systemic and mucosal immune responses, but this response occurred at a less robust level than that in young mice. ${ }^{134,135}$ Flagellin induced an efficient immune response in elderly subjects immunized with a recombinant hemagglutinin influenza-flagellin fusion vaccine (VAX125). ${ }^{136}$ In addition, flagellin has been shown to enhance cross-protective responses of related antigens; for instance, intranasal immunization of mice with recombinant PspA fused to flagellin enhances cross-protective immunity against Streptococcus pneumoniae infection. ${ }^{77}$ All these findings suggest that the benefits and potential of flagellin are unlimited.

\section{CONCLUSION}

Related to the use of flagellin as an adjuvant and anti-tumor agent, there are many areas worthy of continued investigation. What are the long-term consequences of the use of flagellin in the context of dosage and the route of administration? Are other receptors or pathways, besides TLR5 and NLRC4, involved in flagellin perception and/or mediation of immunity in mammals? Do distinctive pathways exist for flagellin in different kinds of cells, for instance, in normal and cancerous cells? To what extent does inflammasome-mediated recognition of flagellin contribute to the overall innate immune response and the adaptive immune response? The answers to these questions should provide a solid basis for the use of flagellin as an effective adjuvant and anti-tumor agent in the future.

In addition, there is accumulating evidence that implicates flagellin for inflammatory diseases, such as acute lung inflammation, cardiovascular collapse, inflammatory bowel disease and lung injury. ${ }^{90,137}$ These effects from the use of flagellin could be minimized or avoided by using very small doses of flagellin or flagellin-based fusion proteins. For instance, 'VaxInnate's Universal Flu Vaccine' has shown in phase 1 clinical study that 0.3 and $1.0 \mu \mathrm{g}$ doses are safe and immunogenic, while 3 and $10 \mu \mathrm{g}$ does were associated with flu-like symptoms. A study by Treanor et al. ${ }^{136}$ in humans has also demonstrated that doses above $3 \mu \mathrm{g}$ have produced moderately severe systemic symptoms accompanied by substantial increases in serum C-reactive protein. Another alternative to minimize toxicity concerns might be the use of a combination of flagellin with another TLR agonist, such as TLR3 or TLR9 ligand, or the use of flagellin in combination with NLRs. These strategies will result in more pronounced effects than individual agonists, especially against tumors ${ }^{36,103}$ and will help reduce the dose of the agonists and toxicity.

\section{CONFLICT OF INTEREST}

The authors declare no conflict of interest.

\section{ACKNOWLEDGEMENTS}

This work was supported by the National Research Foundation of Korea (NRF) in a grant funded by the Korean government (MISP) (No. 2015R1A2A1A14001011).

\section{PUBLISHER'S NOTE}

Springer Nature remains neutral with regard to jurisdictional claims in published maps and institutional affiliations.

1 Schnare M, Barton GM, Holt AC, Takeda K, Akira S, Medzhitov R. Toll-like receptors control activation of adaptive immune responses. Nat Immunol 2001: 2: 947-950.

2 Liew FY, Xu D, Brint EK, O'Neill LAJ. Negative regulation of Toll-like receptor-mediated immune responses. Nat Rev Immunol 2005; 5: 446-458.

3 Akira S, Uematsu S, Takeuchi O. Pathogen recognition and innate immunity. Cell 2006; 124: 783-801.

4 Medzhitov R, Janeway C. Innate immune recognition: mechanisms and pathways. Immunol Rev 2000; 173: 89-97.

5 Kawai T, Akira S. Toll-like receptors and their crosstalk with other innate receptors in infection and immunity. Immunity 2011; 34: 637-650.

6 Akira S, Hemmi H. Recognition of pathogen-associated molecular patterns by TLR family. Immunol Lett 2003; 85: 85-95.

7 Granucci F, Feau S, Zanoni I, Pavelka N, Vizzardelli C, Raimondi G et al. The immune response is initiated by dendritic cells via interaction with 
microorganisms and interleukin-2 production. J Infect Dis 2003; 187: S346-S350.

8 Sharpe AH. Mechanisms of costimulation. Immunol Rev 2009; 229: 5-11.

9 Newton SMC, Wasley RD, Wilson A, Rosenberg LT, Miller JF, Stocker BA. Segment IV of a Salmonella flagellin gene specifies flagellar antigen epitopes. Mol Microbiol 1991; 5: 419-425.

10 Ciacci-Woolwine F, Blomfield IC, Richardson SH, Mizel SB. Salmonella flagellin induces tumor necrosis factor alpha in a human promonocytic cell line. Infect Immun 1998; 66: 1127-1134.

11 Wyant TL, Tanner MK, Sztein MB. Salmonella typhi flagella are potent inducers of proinflammatory cytokine secretion by human monocytes. Infect Immun 1999; 67: 3619-3624.

12 McDermott PF, Ciacci-Woolwine F, Snipes JA, Mizel SB. High-affinity interaction between gram-negative flagellin and a cell surface polypeptide results in human monocyte activation. Infect Immun 2000; 68: 5525-5529.

13 Hayashi F, Means TK, Luster AD. Toll-like receptors stimulate human neutrophil function. Blood 2003; 102: 2660-2669.

14 Eaves-Pyles TD, Wong HR, Odoms K, Pyles RB. Salmonella flagellindependent proinflammatory responses are localized to the conserved amino and carboxyl regions of the protein. J Immunol 2001; 167: 7009-7016.

15 Murthy KGK, Deb A, Goonesekera S, Szabo C, Salzman AL. Identification of Conserved domains in Salmonella muenchen flagellin that are essential for its ability to activate TLR5 and to induce an inflammatory response in vitro. J Biol Chem 2004; 279: 5667-5675.

16 Ben-Yedidia T, Marcus H, Reisner Y, Arnon R. Intranasal administration of peptide vaccine protects human/mouse radiation chimera from influenza infection. Int Immunol 1999; 11: 1043-1051.

17 Ben-Yedidia T, Arnon R. Effect of pre-existing carrier immunity on the efficacy of synthetic influenza vaccine. Immunol Lett 1998; 64: 9-15.

18 Levi R, Arnon R. Synthetic recombinant influenza vaccine induces efficient long-term immunity and cross-strain protection. Vaccine 1996; 14: 85-92.

19 Liu G, Tarbet B, Song L, Reiserova L, Weaver B, Chen Y et al. Immunogenicity and efficacy of flagellin-fused vaccine candidates targeting 2009 pandemic H1N1 influenza in mice. PLOS ONE 2011; 6: e20928.

20 Taylor DN, Treanor JJ, Strout C, Johnson C, Fitzgerald T, Kavita U et al. Induction of a potent immune response in the elderly using the TLR- 5 agonist, flagellin, with a recombinant hemagglutinin influenza-flagellin fusion vaccine (VAX125, STF2. HA1 SI). Vaccine 2011; 29: 4897-4902.

21 Gewirtz AT, Navas TA, Lyons S, Godowski PJ, Madara JL. Cutting edge: bacterial flagellin activates basolaterally expressed TLR5 to induce epithelial proinflammatory gene expression. J Immunol 2001; 167: $1882-1885$

22 Lu J, Sun PD. The structure of the TLR5-flagellin complex: a new mode of pathogen detection, conserved receptor dimerization for signaling. Sci Signal 2012; 5: pe11.

23 Osvaldova A, Woodman S, Patterson N, Offord V, Mwangi D, Gibson AJ et al. Replacement of two aminoacids in the bovine Toll-like receptor 5 TIR domain with their human counterparts partially restores functional response to flagellin. Dev Comp Immunol 2014; 47: 90-94.

24 Tsujimoto H, Uchida T, Efron PA, Scumpia PO, Verma A, Matsumoto T et al. Flagellin enhances NK cell proliferation and activation directly and through dendritic cell-NK cell interactions. Immunol Lett 2009; 125: 114-118.

25 Vicente-Suarez I, Brayer J, Villagra A, Cheng F, Sotomayor EM. TLR5 ligation by flagellin converts tolerogenic dendritic cells into activating antigen-presenting cells that preferentially induce T-helper 1 responses. Immunol Lett 2009; 125: 114-118.

26 Uematsu S, Jang MH, Chevrier N, Guo Z, Kumagai Y, Yamamoto M et al. Detection of pathogenic intestinal bacteria by Toll-like receptor 5 on intestinal CD11C+ lamina propria cells. Nat Immunol 2006; 7: 868-874.

27 Vijay-Kumar M, Aitken JD, Sanders CJ, Frias A, Sloane VM, Xu J et al. Flagellin treatment protects against chemicals, bacteria, viruses, and radiation. J Immunol 2008; 180: 8280-8285.

28 Hajam IA, Dar PA, Sekar SC, Nanda R, Kishore S, Bhanuprakash V et al. Expression, purification, and functional characterisation of flagellin, a TLR5-ligand. Vet Ital 2013; 49: 181-186.

29 Honko AN, Mizel SB. Mucosal administration of flagellin induces innate immunity in the mouse lung. Infect Immun 2004; 72: 6676-6679.
30 Mizel SB, Honko AN, Moors MA, Smith PS, West AP. Induction of macrophage nitric oxide production by Gram-negative flagellin involves signaling via heteromeric Toll-like receptor 5/Toll-like receptor 4 complexes. J Immunol 2003; 170: 6217-6223.

31 Hueck CJ. Type III protein secretion systems in bacterial pathogens of animals and plants. Microbiol Mol Biol Rev 1998; 62: 379-433.

32 Kofoed EM, Vance RE. Innate immune recognition of bacterial ligands by NAIPs determines inflammasome specificity. Nature 2011; 477: 592-595.

33 Franchi L, Amer A, Body-Malapel M, Kanneganti T-D, Özören N, Jagirdar $\mathrm{R}$ et al. Cytosolic flagellin requires I paf for activation of caspase-1 and interleukin $1 \beta$ in Salmonella-infected macrophages. Nat Immunol 2006; 7: $576-582$.

34 Miao EA, Alpuche-Aranda CM, Dors M, Clark AE, Bader MW, Miller SI et al. Cytoplasmic flagellin activates caspase-1 and secretion of interleukin $1 \beta$ via Ipaf. Nat Immunol 2006; 7: 569-575.

35 Lightfield KL, Persson J, Brubaker SW, Witte CE, von Moltke J, Dunipace EA et al. Critical function for Naip5 in inflammasome activation by a conserved carboxy-terminal domain of flagellin. Nat Immunol 2008; 9: $1171-1178$.

36 Garaude J, Blander JM. Attacking tumor cells with a dual ligand for innate immune receptors. Oncotarget 2012; 3: 361-362.

37 Trdá L, Fernandez O, Boutrot F, Héloir M-C, Kelloniemi J, Daire X et al. The grapevine flagellin receptor VvFLS2 differentially recognizes flagellinderived epitopes from the endophytic growth-promoting bacterium Burkholderia phytofirmans and plant pathogenic bacteria. New Phytol 2014; 201: 1371-1384.

38 Asai T, Tena G, Plotnikova J, Willmann MR, Chiu W-L, Gomez-Gomez L et al. MAP kinase signalling cascade in Arabidopsis innate immunity. Nature 2002; 415: 977-983.

39 Hind SR, Strickler SR, Boyle PC, Dunham DM, Bao Z, O'Doherty IM et al. Tomato receptor flagellin-sensing 3 binds flgII-28 and activates the plant immune system. Nat Plants 2016; 2: 16128.

40 Hatai H, Lepelley A, Zeng W, Hayden MS, Ghosh S, West A et al. Toll-like receptor 11 (TLR11) interacts with flagellin and profilin through disparate mechanisms. PLOS ONE 2016; 11: e0148987.

41 Shi Z, Cai Z, Yu J, Zhang T, Zhao S, Smeds E et al. Toll-like receptor 11 (TLR11) prevents Salmonella penetration into the murine Peyer patches. $J$ Biol Chem 2012; 287: 43417-43423.

42 Hajam IA, Dar PA, Chandrasekar S, Nanda RK, Kishore S, Bhanuprakash $\checkmark$ et al. Co-administration of flagellin augments immune responses to inactivated foot-and-mouth disease virus (FMDV) antigen. Res Vet Sci 2013; 95: 936-941.

43 Skountzou I, Martin M, del P, Wang B, Ye L, Koutsonanos D et al. Salmonella flagellins are potent adjuvants for intranasally administered whole inactivated influenza vaccine. Vaccine 2010; 28: 4103-4112.

44 Benko S, Magyarics Z, Szabó A, Rajnavölgyi E. Dendritic cell subtypes as primary targets of vaccines: the emerging role and cross-talk of pattern recognition receptors. Biol Chem 2008; 389: 469-485.

45 Honko AN, Sriranganathan N, Lees CJ, Mizel SB. Flagellin is an effective adjuvant for immunization against lethal respiratory challenge with Yersinia pestis. Infect Immun 2006; 74: 1113-1120.

46 Honko AN, Mizel SB. Effects of flagellin on innate and adaptive immunity. Immunol Res 2005; 33: 083-102.

47 Mizel SB, Bates JT. Flagellin as an adjuvant: cellular mechanisms and potential. J Immunol 2010; 185: 5677-5682.

48 Sanders CJ, Moore DA, Williams IR, Gewirtz AT. Both radioresistant and hemopoietic cells promote innate and adaptive immune responses to flagellin. J Immunol 2008; 180: 7184-7192.

49 Tedla N, Wang H, Mcneil HP, Girolamo D, Hampartzoumian T, Wakefield $\mathrm{D}$ et al. Regulation of T lymphocyte trafficking into lymph nodes during an immune response by the chemokines macrophage inflammatory protein (MIP)-1 $\alpha$ and MIP-1 $\beta . J$ Immunol 1998; 161: 5663-5672.

50 Salazar-Gonzalez R-M, Srinivasan A, Griffin A, Muralimohan G, Ertelt JM, Ravindran $\mathrm{R}$ et al. Salmonella flagellin induces bystander activation of splenic dendritic cells and hinders bacterial replication in vivo. J Immunol 2007; 179: 6169-6175.

51 Agrawal S, Agrawal A, Doughty B, Gerwitz A, Blenis J, Van Dyke T et al. Cutting edge: different Toll-like receptor agonists instruct dendritic cells to induce distinct Th responses via differential modulation of extracellular signal-regulated kinase-mitogen-activated protein kinase and c-Fos. J Immunol 2003; 171: 4984-4989.

52 Arimilli S, Johnson JB, Clark KM, Graff AH, Alexander-Miller MA, Mizel SB et al. Engineered expression of the TLR5 ligand flagellin enhances 
paramyxovirus activation of human dendritic cell function. J Virol 2008; 82: 10975-10985.

53 Uematsu S, Fujimoto K, Jang MH, Yang B-G, Jung Y-J, Nishiyama M et al. Regulation of humoral and cellular gut immunity by lamina propria dendritic cells expressing Toll-like receptor 5. Nat Immunol 2008; 9: 769-776.

54 Datta SK, Redecke V, Prilliman KR, Takabayashi K, Corr M, Tallant T et al. A subset of Toll-like receptor ligands induces cross-presentation by bone marrow-derived dendritic cells. J Immunol 2003; 170 : 4102-4110.

55 Didierlaurent A, Ferrero I, Otten LA, Dubois B, Reinhardt M, Carlsen H et al. Flagellin promotes myeloid differentiation factor 88-dependent development of Th2-type response. J Immunol 2004; 172: 6922-6930.

56 Means TK, Hayashi F, Smith KD, Aderem A, Luster AD. The Toll-like receptor 5 stimulus bacterial flagellin induces maturation and chemokine production in human dendritic cells. J Immunol 2003; 170: 5165-5175.

57 Nossal G, Ada G, Austin CM. Antigens in immunity. Aust J Exp Biol Med Sci 1964; 42: 311-330.

58 Andersen-Nissen E, Smith KD, Strobe KL, Barrett SLR, Cookson BT, Logan SM et al. Evasion of Toll-like receptor 5 by flagellated bacteria. Proc Natl Acad Sci USA 2005; 102: 9247-9252.

59 Yonekura K, Maki-Yonekura S, Namba K. Complete atomic model of the bacterial flagellar filament by electron cryomicroscopy. Nature 2003; 424 643-650.

60 Galkin VE, Yu X, Bielnicki J, Heuser J, Ewing CP, Guerry P et al. Divergence of quaternary structures among bacterial flagellar filaments. Science 2008; 320: 382-385.

61 Song WS, Jeon YJ, Namgung B, Hong M, Yoon S-I. A conserved TLR5 binding and activation hot spot on flagellin. Sci Rep 2017; 7: 40878.

62 McCarron M, Reen DJ. Activated human neonatal CD8 ${ }^{+} \mathrm{T}$ cells are subject to immunomodulation by direct TLR2 or TLR5 stimulation. J Immunol 2009; 182: 55-62.

63 Crellin NK, Garcia RV, Hadisfar O, Allan SE, Steiner TS, Levings MK. Human $\mathrm{CD}^{+}{ }^{+} \mathrm{T}$ cells express TLR5 and its ligand flagellin enhances the suppressive capacity and expression of FOXP3 in $\mathrm{CD}^{+} \mathrm{CD} 25^{+} \mathrm{T}$ regulatory cells. J Immunol 2005; 175: 8051-8059.

64 Okugawa S, Yanagimoto S, Tsukada K, Kitazawa T, Koike K, Kimura S et al. Bacterial flagellin inhibits $T$ cell receptor-mediated activation of $\mathrm{T}$ cells by inducing suppressor of cytokine signalling-1 (SOCS-1). Cell Microbiol 2006; 8: 1571-1580.

65 Pasare C, Medzhitov R. Control of B-cell responses by Toll-like receptors. Nature 2005; 438: 364-368.

66 Sanders CJ, Yu Y, Moore DA, Williams IR, Gewirtz AT. Humoral immune response to flagellin requires $T$ cells and activation of innate immunity. J Immunol 2006; 177: 2810-2818.

67 Bennett KM, Gorham RD, Gusti V, Trinh L, Morikis D, Lo DD. Hybrid flagellin as a T cell independent vaccine scaffold. BMC Biotechnol 2015; 15: 71 .

68 Vijay-Kumar M, Carvalho FA, Aitken JD, Fifadara NH, Gewirtz AT. TLR5 or NLRC4 is necessary and sufficient for promotion of humoral immunity by flagellin. Eur J Immunol 2010; 40: 3528-3534.

69 Lopez-Yglesias AH, Zhao X, Quarles EK, Lai MA, VandenBos T, Strong RK et al. Flagellin induces antibody responses through a TLR5- and inflammasome-independent pathway. J Immunol 2014; 192 1587-1596

70 Adar Y, Singer Y, Levi R, Tzehoval E, Perk S, Banet-Noach C et al. A universal epitope-based influenza vaccine and its efficacy against H5N1. Vaccine 2009; 27: 2099-2107.

71 Ben-Yedidia T, Arnon R. Epitope-based vaccine against influenza. Expert Rev Vaccines 2007; 6: 939-948.

72 McDonald WF, Huleatt JW, Foellmer HG, Hewitt D, Tang J, Desai P et al. A West Nile virus recombinant protein vaccine that coactivates innate and adaptive immunity. J Infect Dis 2007; 195: 1607-1617.

73 Sbrogio-Almeida ME, Cabilio Guth BE, Castilho BA, Pereira CM. Antibody response against Escherichia coli heat-stable enterotoxin expressed as fusions to flagellin. Microbiol 2001; 147: 861-867.

74 Mizel SB, Graff AH, Sriranganathan N, Ervin S, Lees CJ, Lively MO et al. Flagellin-F1-V fusion protein is an effective plague vaccine in mice and two species of nonhuman primates. Clin Vaccine Immunol 2009; 16: 21-28.

75 Lee SE, Kim SY, Jeong BC, Kim YR, Bae SJ, Ahn OS et al. A bacterial flagellin, Vibrio vulnificus FlaB, has a strong mucosal adjuvant activity to induce protective immunity. Infect Immun 2006; 74: 694-702.
76 Huang J, Yin Y-X, Pan Z, Zhang G, Zhu A, Liu X et al. Intranasal immunization with chitosan/pCAGGS- fla a nanoparticles inhibits Campylobacter jejuni in a white leghorn model. J Biomed Biotechnol 2010; 2010: 1-8.

77 Nguyen CT, Kim SY, Kim MS, Lee SE, Rhee JH. Intranasal immunization with recombinant PspA fused with a flagellin enhances cross-protective immunity against Streptococcus pneumoniae infection in mice. Vaccine 2011; 29: 5731-5739.

78 Bargieri DY, Rosa DS, Braga CJM, Carvalho BO, Costa FTM, Espíndola NM et al. New malaria vaccine candidates based on the Plasmodium vivax merozoite surface protein- 1 and the TLR-5 agonist Salmonella typhimurium FliC flagellin. Vaccine 2008; 26: 6132-6142.

79 Camacho AGA, Teixeira LH, Bargieri DY, Boscardin SB, Soares I, da S et al. TLR5-dependent immunogenicity of a recombinant fusion protein containing an immunodominant epitope of malarial circumsporozoite protein and the FliC flagellin of Salmonella Typhimurium. Mem Inst Oswaldo Cruz 2011; 106(Suppl 1): 167-171.

80 Eaves-Pyles T, Murthy K, Liaudet L, Virág L, Ross G, Soriano FG et al. Flagellin, a novel mediator of Salmonella-induced epithelial activation and systemic inflammation: I kappa B alpha degradation, induction of nitric oxide synthase, induction of proinflammatory mediators, and cardiovascular dysfunction. J Immunol 2001; 166: 1248-1260.

81 Berin MC, Darfeuille-Michaud A, Egan LJ, Miyamoto Y, Kagnoff MF. Role of EHEC 0157:H7 virulence factors in the activation of intestinal epithelial cell NF-kappaB and MAP kinase pathways and the upregulated expression of interleukin 8. Cell Microbiol 2002; 4: 635-648.

82 Steiner TS, Nataro JP, Poteet-Smith CE, Smith JA, Guerrant RL. Enteroaggregative Escherichia coli expresses a novel flagellin that causes IL-8 release from intestinal epithelial cells. J Clin Invest 2000; 105: 1769-1777.

83 Sierro F, Dubois B, Coste A, Kaiserlian D, Kraehenbuhl J-P, Sirard J-C. Flagellin stimulation of intestinal epithelial cells triggers CCL20-mediated migration of dendritic cells. Proc Natl Acad Sci USA 2001; 98: 13722-13727.

84 Zeng H, Carlson AQ, Guo Y, Yu Y, Collier-Hyams LS, Madara JL et al. Flagellin is the major proinflammatory determinant of enteropathogenic Salmonella. J Immunol 2003; 171: 3668-3674.

85 Ramos HC, Rumbo M, Sirard J-C. Bacterial flagellins: mediators of pathogenicity and host immune responses in mucosa. Trends Microbiol 2004; 12: 509-517.

86 Tezuka H, Abe Y, Iwata M, Takeuchi H, Ishikawa H, Matsushita M et al. Regulation of IgA production by naturally occurring TNF/iNOS-producing dendritic cells. Nature 2007; 448: 929-933.

87 Tezuka $\mathrm{H}$, Abe Y, Asano J, Sato T, Liu J, Iwata M et al. Prominent role for plasmacytoid dendritic cells in mucosal T cell-independent IgA induction. Immunity 2011; 34: 247-257.

88 Zhao X, Deak E, Soderberg K, Linehan M, Spezzano D, Zhu J et al. Vaginal submucosal dendritic cells, but not langerhans cells, induce protective Th1 responses to herpes simplex virus-2. J Exp Med 2003; 197 153-162.

89 Ramsay AJ, Husband AJ, Ramshaw IA, Bao S, Matthaei KI, Koehler G et al. The role of interleukin- 6 in mucosal IgA antibody responses in vivo. Science 1994; 264: 561-563.

90 Lodes MJ, Cong Y, Elson CO, Mohamath R, Landers CJ, Targan SR et al. Bacterial flagellin is a dominant antigen in Crohn disease. J Clin Invest 2004; 113: 1296-1306.

91 Holmgren J, Czerkinsky C. Mucosal immunity and vaccines. Nat Med 2005; 11: S45-S53.

92 Worbs T, Bode U, Yan S, Hoffmann MW, Hintzen G, Bernhardt G et al. Oral tolerance originates in the intestinal immune system and relies on antigen carriage by dendritic cells. J Exp Med 2006; 203: 519-527.

93 Girard A, Saron W, Bergeron-Sandoval L-P, Sarhan F, Archambault D. Flagellin produced in plants is a potent adjuvant for oral immunization. Vaccine 2011 ; 29: 6695-6703.

94 Hawn TR, Verbon A, Lettinga KD, Zhao LP, Li SS, Laws RJ et al. A common dominant TLR5 stop codon polymorphism abolishes flagellin signaling and is associated with susceptibility to legionnaires' disease. J Exp Med 2003; 198: 1563-1572.

95 Raeburn CD, Calkins CM, Zimmerman MA, Arya J, Barsness KA, Harken $\mathrm{AH}$. Toll-like receptors and surgical disease. Surgery 2002; 131: 477-483.

96 Stockfleth E, Trefzer U, Garcia-Bartels C, Wegner T, Schmook T, Sterry W. The use of Toll-like receptor-7 agonist in the treatment of basal cell carcinoma: an overview. Br J Dermatol 2003; 149: 53-56. 
97 Okamoto M, Sato M. Toll-like receptor signaling in anti-cancer immunity. J Med Invest 2003; 50: 9-24.

98 Kelly MG, Alvero AB, Chen R, Silasi D-A, Abrahams VM, Chan S et al. TLR-4 signaling promotes tumor growth and paclitaxel chemoresistance in ovarian cancer. Cancer Res 2006; 66: 3859-3868.

99 Szczepanski MJ, Czystowska M, Szajnik M, Harasymczuk M, Boyiadzis M, Kruk-Zagajewska A et al. Triggering of Toll-like receptor 4 expressed on human head and neck squamous cell carcinoma promotes tumor development and protects the tumor from immune attack. Cancer Res 2009; 69: 3105-3113.

100 Chiron D, Pellat-Deceunynck C, Maillasson M, Bataille R, Jego G. Phosphorothioate-modified TLR9 ligands protect cancer cells against TRAIL-induced apoptosis. J Immunol 2009; 183: 4371-4377.

101 Schmaußer B, Andrulis M, Endrich S, Müller-Hermelink H-K, Eck M. Tolllike receptors TLR4, TLR5 and TLR9 on gastric carcinoma cells: an implication for interaction with Helicobacter pylori. Int J Med Microbiol 2005; 295: 179-185.

102 Salaun B, Coste I, Rissoan M-C, Lebecque SJ, Renno T. TLR3 can directly trigger apoptosis in human cancer cells. J Immunol 2006; 176: 4894-4901.

103 Sfondrini L, Rossini A, Besusso D, Merlo A, Tagliabue E, Mènard S et al. Antitumor activity of the TLR-5 ligand flagellin in mouse models of cancer. J Immunol 2006; 176: 6624-6630.

104 Maerten P, Shen C, Bullens DMA, Van Assche G, Van Gool S, Geboes K et al. Effects of interleukin 4 on $C D 25+C D 4+$ regulatory $T$ cell function. $J$ Autoimmun 2005; 25: 112-120.

105 Napolitani G, Rinaldi A, Bertoni F, Sallusto F, Lanzavecchia A. Selected Toll-like receptor agonist combinations synergistically trigger a $T$ helper type 1-polarizing program in dendritic cells. Nat Immunol 2005; 6 : 769-776.

106 Zheng JH, Nguyen VH, Jiang S, Park S, Tan W, Hong SH et al. Two-step enhanced cancer immunotherapy with engineered Salmonella typhimurium secreting heterologous flagellin. Science Trans/ Med 2017; 9537: $1-11$.

107 Kanzler H, Barrat FJ, Hessel EM, Coffman RL. Therapeutic targeting of innate immunity with Toll-like receptor agonists and antagonists. Nat Med 2007; 13: 552-559.

108 Tukhvatulin AI, Gitlin II, Shcheblyakov DV, Artemicheva NM, Burdelya LG, Shmarov MM et al. Combined stimulation of Toll-like receptor 5 and NOD1 strongly potentiates activity of NF- B, resulting in enhanced innate immune reactions and resistance to Salmonella enterica serovar typhimurium infection. Infect Immun 2013; 81: 3855-3864.

109 Yu X, Guo C, Yi H, Qian J, Fisher PB, Subjeck JR et al. A multifunctional chimeric chaperone serves as a novel immune modulator inducing therapeutic antitumor immunity. Cancer Res 2013; 73: 2093-2103.

110 Kaczanowska S, Davila E. Ameliorating the tumor microenvironment for antitumor responses through TLR5 ligand-secreting T cells. Oncoimmunology 2016; 5: e1076609.

111 Leigh ND, Bian G, Ding X, Liu H, Aygun-Sunar S, Burdelya LG et al. A flagellin-derived toll-like receptor 5 agonist stimulates cytotoxic lymphocyte-mediated tumor immunity. PLoS ONE 2014; 9: e85587.

112 Burdelya LG, Brackett CM, Kojouharov B, Gitlin II, Leonova KI, Gleiberman AS et al. Central role of liver in anticancer and radioprotective activities of Toll-like receptor 5 agonist. Proc Natl Acad Sci USA 2013; 110: E1857-E1866.

113 Brackett CM, Kojouharov B, Veith J, Greene KF, Burdelya LG, Gollnick SO et al. Toll-like receptor-5 agonist, entolimod, suppresses metastasis and induces immunity by stimulating an NK-dendritic-CD8 ${ }^{+}$T-cell axis. Proc Natl Acad Sci USA 2016; 113: E874-E883.

114 Kauppila JH, Mattila AE, Karttunen TJ, Salo T. Toll-like receptor 5 (TLR5) expression is a novel predictive marker for recurrence and survival in squamous cell carcinoma of the tongue. $\mathrm{Br}$ J Cancer 2013; 108: 638-643.

115 Rhee SH, Im E, Pothoulakis C. Toll-like receptor 5 engagement modulates tumor development and growth in a mouse xenograft model of human colon cancer. Gastroenterology 2008; 135: 518-528.

116 Hasan UA, Trinchieri G, Vlach J. Toll-like receptor signaling stimulates cell cycle entry and progression in fibroblasts. J Biol Chem 2005; 280: 20620-20627.

117 Nguyen CT, Hong SH, Sin J-I, Vu HVD, Jeong K, Cho KO et al. Flagellin enhances tumor-specific CD8+ T cell immune responses through TLR5 stimulation in a therapeutic cancer vaccine model. Vaccine 2013; 31: 3879-3887.
118 Citrin D, Cotrim AP, Hyodo F, Baum BJ, Krishna MC, Mitchell JB. Radioprotectors and mitigators of radiation-induced normal tissue injury. Oncologist 2010; 15: 360-371.

119 Burdelya LG, Krivokrysenko VI, Tallant TC, Strom E, Gleiberman AS, Gupta $\mathrm{D}$ et al. An agonist of toll-like receptor 5 has radioprotective activity in mouse and primate models. Science 2008; 320: 226-230.

120 Lacavé-Lapalun J-V, Benderitter M, Linard C. Flagellin or lipopolysaccharide treatment modified macrophage populations after colorectal radiation of rats. J Pharmacol Exp Ther 2013; 346: 75-85.

121 Rojas M, Woods CR, Mora AL, Xu J, Brigham KL. Endotoxin-induced lung injury in mice: structural, functional, and biochemical responses. AJP Lung Cell Mol Physiol 2004; 288: L333-L341.

122 Wani MY, Goswami TK, Chaudhary D, Singh R, Dhama K. Mitigation of septic signs by pravastatin during LPS co-administered hen-egg white lysozyme immunization in mice. Int J Pharmacol 2014; 10: 389-397.

123 Gewirtz AT. Intestinal epithelial toll-like receptors: to protect. And serve? Curr Pharm Des 2003; 9: 1-5.

124 Jung HC, Eckmann L, Yang SK, Panja A, Fierer J, Morzycka-Wroblewska E et al. A distinct array of proinflammatory cytokines is expressed in human colon epithelial cells in response to bacterial invasion. J Clin Invest 1995; 95: 55-65.

125 Lee SE, Koh YI, Kim M-K, Kim YR, Kim SY, Nam JH et al. Inhibition of airway allergic disease by co-administration of flagellin with allergen. $J$ Clin Immunol 2008; 28: 157-165.

126 Petrof EO, Musch MW, Ciancio M, Sun J, Hobert ME, Claud EC et al. Flagellin is required for Salmonella-induced expression of heat shock protein Hsp25 in intestinal epithelium. Am J Physiol Gastrointest Liver Physiol 2008; 294: G808-G818.

127 Kojouharov BM, Brackett CM, Veith JM, Johnson CP, Gitlin II, Toshkov IA et al. Toll-like receptor-5 agonist Entolimod broadens the therapeutic window of 5 -fluorouracil by reducing its toxicity to normal tissues in mice. Oncotarget 2014; 5: 802-814.

128 Song L, Nakaar V, Kavita U, Price A, Huleatt J, Tang J et al. Efficacious recombinant influenza vaccines produced by high yield bacterial expression: a solution to global pandemic and seasonal needs. PLOS ONE 2008; 3: e2257.

129 Song L, Zhang Y, Yun NE, Poussard AL, Smith JN, Smith JK et al. Superior efficacy of a recombinant flagellin: H5N1 HA globular head vaccine is determined by the placement of the globular head within flagellin. Vaccine 2009; 27: 5875-5884.

130 Liu G, Song L, Reiserova L, Trivedi U, Li H, Liu X et al. Flagellin-HA vaccines protect ferrets and mice against $\mathrm{H} 5 \mathrm{~N} 1$ highly pathogenic avian influenza virus (HPAIV) infections. Vaccine 2012; 30: 6833-6838.

131 Wang B-Z, Quan F-S, Kang S-M, Bozja J, Skountzou I, Compans RW. Incorporation of membrane-anchored flagellin into influenza virus-like particles enhances the breadth of immune responses. J Virol 2008; 82: 11813-11823.

132 McSorley SJ, Ehst BD, Yu Y, Gewirtz AT. Bacterial flagellin is an effective adjuvant for CD4+ T cells in vivo. J Immunol 2002; 169: 3914-3919.

133 McSorley SJ, Cookson BT, Jenkins MK. Characterization of CD4+ T cell responses during natural infection with Salmonella typhimurium. J Immunol 2000; 164: 986-993.

134 Ben-Yedidia T, Abel L, Arnon R, Globerson A. Efficacy of anti-influenza peptide vaccine in aged mice. Mech Ageing Dev 1998; 104: 11-23.

135 Bates JT, Honko AN, Graff AH, Kock ND, Mizel SB. Mucosal adjuvant activity of flagellin in aged mice. Mech Ageing Dev 2008; 129: 271-281.

136 Treanor JJ, Taylor DN, Tussey L, Hay C, Nolan C, Fitzgerald T et al. Safety and immunogenicity of a recombinant hemagglutinin influenza-flagellin fusion vaccine (VAX125) in healthy young adults. Vaccine 2010; 28: 8268-8274.

137 Xiao Y, Liu F, Yang J, Zhong M, Zhang E, Li Y et al. Over-activation of TLR5 signaling by high-dose flagellin induces liver injury in mice. Cell Mol Immunol 2015; 12: 729-742.

138 Ben-Yedidia T, Tarrab-Hazdai R, Schechtman D, Arnon R. Intranasal administration of synthetic recombinant peptide-based vaccine protects mice from infection by Schistosoma mansoni. Infect Immun 1999; 67: 4360-4366.

139 Lee LH, Burg E, Baqar S, Bourgeois AL, Burr DH, Ewing CP et al. Evaluation of a truncated recombinant flagellin subunit vaccine against Campylobacter jejuni. Infect Immun 1999; 67: 5799-5805.

140 Le Moigne V, Robreau G, Mahana W. Flagellin as a good carrier and potent adjuvant for Th1 response: Study of mice immune response to the 
p27 (Rv2108) Mycobacterium tuberculosis antigen. Mol Immunol 2008; 45: 2499-2507.

141 Weimer ET, Lu H, Kock ND, Wozniak DJ, Mizel SB. A fusion protein vaccine containing OprF epitope 8 , Oprl, and type $A$ and $B$ flagellins promotes enhanced clearance of nonmucoid Pseudomonas aeruginosa. Infect Immun 2009; 77: 2356-2366.

142 Asadi Karam MR, Oloomi M, Mahdavi M, Habibi M, Bouzari S. Vaccination with recombinant FimH fused with flagellin enhances cellular and humoral immunity against urinary tract infection in mice. Vaccine 2013; 31: 1210-1216.

143 Rady HF, Dai G, Huang W, Shellito JE, Ramsay AJ, Li Y. Flagellin encoded in gene-based vector vaccines is a route-dependent immune adjuvant. PLoS ONE 2016; 11: e0148701.

144 Hiriart Y, Rossi AH, Biedma ME, Errea AJ, Moreno G, Cayet D et al. Characterization of structural and immunological properties of a fusion protein between flagellin from Salmonella and lumazine synthase from Brucella. Protein Sci 2017; 26: 1049-1059.

145 Delaney KN, Phipps JP, Johnson JB, Mizel SB. A recombinant flagellinpoxvirus fusion protein vaccine elicits complement-dependent protection against respiratory challenge with vaccinia virus in mice. Viral Immunol 2010; 23: 201-210.

146 Vassilieva EV, Wang B, Vzorov AN. Enhanced mucosal immune responses to HIV virus-like particles containing a membrane-anchored adjuvant. MBio 2011; 15: e00328-10.

147 Qi Y, Kang H, Zheng X, Wang H, Gao Y, Yang S et al. Incorporation of membrane-anchored flagellin or Escherichia coli heat-labile enterotoxin B subunit enhances the immunogenicity of rabies virus-like particles in mice and dogs. Front Microbiol 2015; 6: 169.

148 Bargieri DY, Rosa DS, Braga CJM, Carvalho BO, Costa FTM, Espíndola NM et al. New malaria vaccine candidates based on the Plasmodium vivax merozoite surface protein-1 and the TLR-5 agonist Salmonella typhimurium FliC flagellin. Vaccine 2008; 26: 6132-6142.

149 Braga CJM, Massis LM, Sbrogio-Almeida ME, Alencar BCG, Bargieri DY, Boscardin SB et al. CD8 ${ }^{+}$T cell adjuvant effects of Salmonella FliCd flagellin in live vaccine vectors or as purified protein. Vaccine 2010; 28: 1373-1382.

150 Yin G, Qin M, Liu X, Suo J, Tang X, Tao G et al. An Eimeria vaccine candidate based on Eimeria tenella immune mapped protein 1 and the TLR-5 agonist Salmonella typhimurium FliC flagellin. Biochem Biophys Res Commun 2013; 440: 437-442.

151 Cuadros C, Lopez-hernandez FJ, Dominguez AL, Mcclelland M, Lustgarten $\mathrm{J}$. Flagellin fusion proteins as adjuvants or vaccines induce specific immune responses. Infect Immun 2004; 72: 2810-2816.

152 Huleatt JW, Jacobs AR, Tang J, Desai P, Kopp EB, Huang Y et al. Vaccination with recombinant fusion proteins incorporating Toll-like receptor ligands induces rapid cellular and humoral immunity. Vaccine 2007; 25: 763-775.

153 Nyström S, Bråve A, Falkeborn T, Devito C, Rissiek B, Johansson D et al. DNA-encoded flagellin activates Toll-like receptor 5 (TLR5), nod-like receptor family CARD domain-containing protein 4 (NRLC4), and acts as an epidermal, systemic, and mucosal-adjuvant. Vaccines 2013; 1 : 415-443.

154 Lockner JW, Eubanks LM, Choi JL, Lively JM, Schlosburg JE, Collins KC et al. Flagellin as carrier and adjuvant in cocaine vaccine development. Mol Pharm 2015; 12: 653-662.

155 Cai Z, Sanchez A, Shi Z, Zhang T, Liu M, Zhang D. Activation of Toll-like Receptor 5 on breast cancer cells by flagellin suppresses cell proliferation and tumor growth. Cancer Res 2011; 71: 2466-2475.

156 Shi M, Yao Y, Han F, Li Y, Li Y, Takeuchi O et al. MAP1S controls breast cancer cell TLR5 signaling pathway and promotes TLR5 signaling-based tumor suppression. PLoS ONE 2014; 9: e86839.

157 Izidoro MS Jr, Varela JN, Alves DA, Pereira RFC, Brocchi M, Lancellotti M et al. Effects of Salmonella enteritidis serovar typhimurium infection in adenocarcinomic human alveolar basal epithelial cells A549 in vitro: bacteria induce apoptosis in adenocarcinomic cell. J Bacteriol Parasitol 2012; 3: 158.

158 Machluf N, Arnon R. Therapeutic MUC1-based cancer vaccine expressed in flagella-efficacy in an aggressive model of breast cancer. World $\mathrm{J}$ Vaccines 2012; 2: 109-120.

159 de Melo FM, Braga CJ, Pereira FV, Maricato JT, Origassa CS, Souza MF et al. Anti-metastatic immunotherapy based on mucosal administration of flagellin and immunomodulatory P10. Immunol Cell Biol 2015; 93: 86-98.

(i) (2) (2) This work is licensed under a Creative Commons Attribution-NonCommercial-ShareAlike 4.0 International License. The images or other third party material in this article are included in the article's Creative Commons license, unless indicated otherwise in the credit line; if the material is not included under the Creative Commons license, users will need to obtain permission from the license holder to reproduce the material. To view a copy of this license, visit http:// creativecommons.org/licenses/by-nc-sa/4.0/

(C) The Author(s) 2017 